\title{
Három hónapos szenzomotoros torna hatása az óvodások és kisiskolások egyensúlyozó képességére
}

\author{
Csirkés Zsolt ${ }^{1}$ és Csongor Nóra Erika ${ }^{2}$ \\ ${ }^{1}$ Testnevelési Egyetem Torna, RG, Tánc és Aerobik Tanszék \\ ${ }^{2}$ Középiskolai Testnevelö-Gyógytestnevelö-Egészségfejlesztö tanárszak, \\ Testnevelési Egyetem
}

\begin{abstract}
Absztrakt
Vizsgálatunk célja bebizonyítani, hogy egy három hónapos szenzomotoros torna hatására a vizsgálati csoportba tartozó gyermekek egyensúlyértékei javulnak, valamint az, hogy a speciális fejlesztő tornákon résztvevő gyermekek jobb eredményt érnek el a kontrollcsoportban szereplő társaikhoz képest. Kutatásunkban 36 óvodásés 41 iskoláskorú gyermek vett részt. A gyermekeket két vizsgálati csoportra (VO, VI) és két kontrollcsoportra (KO, KI) osztottuk. VO csoport (5-6 éves óvodások) és VI csoport (7-10 éves kisiskolások) három hónapon keresztül heti 2x60 perces szenzomotoros tornán vett részt, a kontrollcsoportba tartozó óvodások (KO), illetve kisiskolások (KI) pedig az óvodai testnevelés és az iskolai mindennapos testnevelés programját követték. Mind a négy csoport dinamikus egyensúlyát talaj- és emelt gerendán mértük a három hónapos fejlesztés előtt és után. A vizsgálati csoportok eredményei közötti eltéréseket külön az 1 . mérésen és külön a 2 . mérésen belül varianciaanalízissel vizsgáltuk. Ezt követően elemeztük a két mérés közötti eltéréseket páros t-próbákkal. Ahol a feltételek nem teljesültek, a méréseken belül a csoportok összehasonlítására Mann-Whitney U-próbát, a két mérés közötti teljesítménybéli különbségeket pedig Wilcoxon-próbával teszteltük. Az eredményekből megállapítottuk, hogy az intervenció hatására a vizsgálati csoportban szereplő 5-6 éves óvodás és 7-10 éves iskolás gyermekek jobban teljesítettek a második mérés alkalmával a gerendán megtett távolság értékek tekintetében az első méréshez képest. Az időeredményeket vizsgálva egyik korosztálynál egyik mérésén belül sem volt szignifikáns mértékủ eltérés a vizsgálati és a kontrollcsoport teljesítményei között.
\end{abstract}

Kulcsszavak: egyensúly, óvodások, iskolások, szenzomotoros torna, rugalmas felület

\section{Bevezetés}

A gyermekkori fejlődés egy igen összetett folyamat, melynek biológiailag determinált természetes összetevője van. Erre nagymértékben kihat az egyén környezete, azonban ezek elválaszthatatlanok egymástól, egyik a másik hiá- 
nyában nem müködhet optimálisan. A gyermekkori mozgásfejlődésben tehát a mozgás a környezettel történő kapcsolattartás eszköze, általa indulnak fejlődésnek a szervek és szervrendszerek (például idegrendszer, csont- és izomrendszer). A kifejtett hatás kétpólusú, mivel a mozgások során fejlődő ideg- és mozgatórendszer egyre bonyolultabb mozgások elsajátítását teszi lehetővé. Valójában a mozgatórendszert célirányosan érintő fejlesztés olyan pszichés funkciójavulást is eredményez, melynek a későbbi kognitív folyamatok kialakulásában lényeges szerepe van. A 10-12 éves korig megvalósuló igényes fejlesztés jelenti az alapját a később erre ráépülő bonyolultabb mozgásoknak. Az idegrendszer érése és a végrehajtható mozgások szoros összefüggésben vannak egymással. A fejlődő idegrendszer által képesek leszünk egyre bonyolultabb mozgások szabályozására, a mozgások folyamatos gyakorlása pedig visszahat az idegrendszer tökéletesedésére, mely feltételezi az újabb mozgások elsajátítását. Ebben a szakaszban a mozgásnak az idegrendszer funkcionális fejlődésében pótolhatatlan szerepe van. Nemcsak a mozgásos ügyesség megalapozása történik meg tehát ebben az életkorban, hanem az egész személyiséget meghatározó képességeké is. A fejlesztés egy egységes, szakaszaiban egymással összefüggő egész, ahol a fejlesztő munkát a gyermek fiziológiai, pedagógiai és pszichológiai sajátosságainak figyelembevételével lehet csak hatékonyan müvelni (Király \& Szakály, 2011).

A mozgás javításában elengedhetetlen az egyensúlyérzék fejlesztése. Az egyensúly érzékelését a test- és izomérzékelési (kinesztetikus), a tapintási, a vizuális és a vesztibuláris analizátorok együttesen segítik (Nagykáldi, 1971).

Az egyensúlyozó képességet számos szerző úgy definiálja, hogy az a képesség, amellyel képesek vagyunk a test tömegközéppontját az alátámasztási felület felett megtartani (Westcott et al., 1997; Sarabon et al., 2010). Mások az egyensúlyérzéken olyan koordinációs képességet értenek, amelynek alapvető követelménye a mozgásfeladatok célszerủ és gyors megoldása, amikor az alátámasztási felület csekély, illetve amikor az egyensúlyi viszonyok rendkívül bizonytalanok (Koltai \& Nádori, 1983; Harsányi, 2000). Nádori (1991) a mozgás lényeges ügyességi tényezőjeként írta le az egyensúlyozó képességet. Pappné (2009) a koordinációs képességek közül az egyensúlyozó képességet tartja leginkább olyan készségnek, amelynek fejlettsége túlnyomó többségben kihat a mozgásszervezés, valamint a mozgásvégrehajtás minőségére. Dubecz (2009) szerint az egyensúlyozás magas szinten való megjelenése minden sportmozgás alapját képezi, melynek idegrendszeri szabályozottsága összetett.

A mindennapi életben, és így a sportmozgásokban is, a test nyugalmi állapotban való stabil helyzetének megtartásán kívül az egyensúlyra olyan képességként tekintünk, amely segíti ezt a stabil testhelyzetet fenntartani mozgás közben is. Ennek értelmében beszélünk statikus és dinamikus egyensúlyról. Pappné (2009) a statikus és dinamikus egyensúly mellett megkülönböztet még tárgyi egyensúlyt is. A statikus egyensúly a felelős a fej térbeli helyzetének és az egyenes vonalú gyorsulásnak az érzékeléséért. A dinamikus egyensúly érzékeli a szögsebességet és a gyors sebességváltozásokat. A tárgyi egyensúly pedig a tárgyak hordását, 
egyensúlyozását jelenti. Ezzel szemben Hirtz és munkatársai (2004) egy újabb besorolás szerint stabilitási, haladási, forgási és repülési egyensúlyt különböztetnek meg. Stabilitási egyensúly alatt a testi egyensúly fenntartására és visszaállítására törekszik, helyváltoztatás nélküli mozdulatoknál. Haladási egyensúlynál is ugyanez a cél, azzal a különbséggel, hogy jelen esetben helyzetváltoztató mozgások közben kell a testi egyensúlyt fenntartani, valamint visszaállítani. Forgási egyensúly alatt a testi egyensúly fenntartására és visszaállítására törekszik, miközben a test különböző tengelyei körül forgó mozgásokat végez. Végül pedig repülési egyensúly alatt azt az állapotot értik, amikor a támasz nélküli repülési fázisban kell a testi egyensúlyt fenntartani, illetve visszaállítani.

A dinamikus egyensúlyozó képességnek egyaránt fontos szerepe van a sportágspecifikus és mindennapi szituációkban, ezért mérésre alkalmas pálya- és laboratóriumi tesztek állnak a rendelkezésünkre (Meszler et al., 2015).

- Séta a gerendán teszt (http://www.topendsports.com/testing/tests/balance-beam.htm)

- Módosított szlalom teszt (http://www.topendsports.com/testing/tests/ balance-bass.htm)

- Négy négyzet teszt (Meszler et al., 2015)

- Csillag egyensúly vizsgálat (Kinzey \& Armstrong, 1998; Gribble \& Hertel, 2003; Reiman, 2009)

- Járásvizsgálat (Wrisley \& Kumar, 2010)

- Tinetti-féle POMA-teszt (Tinetti, 1986)

- Stabilometriai vizsgálatok (Fruttus, 1981; Gyebnár, 1982; Rácz \& Bretz, 2008)

A szakirodalomban számos ajánlással találkozhatunk az egyensúlyozó képesség fejlesztésével kapcsolatban. F. Földi és Boda-Ujlaky (2014) szerint a mozgásszabályozás kezdetben egyensúlyi irányítás alatt áll. Az egyensúlyi rendszer érző sejtjeinek érése a 8-10. magzati héten indul meg, ekkor mozgásingerlésre az első válaszok már kiválthatók. A 12. magzati héten jelennek meg az első egyensúlyi reflexek. 16 hetes magzati kor körül az anya hirtelen mozdulatára, testhelyzete változtatására a magzat orientációs mozgásokat végez a magzatvízben. Az újszülött az első pillanattól kezdve szembesül a magzatvíz által már nem tompított nehézségi erővel, amelyhez az egyensúlyi rendszere által tud alkalmazkodni, s a gravitáció ellen való megküzdés árán jut el a mozgásfejlődési szintekre. Az egyensúlyérzék fejlesztését a gyermekét ringató édesanya már közvetlenül a születés után elkezdi. Fontos, hogy az első hónapokban a vesztibuláris rendszer összhangba kerüljön a többi érzékszervvel, hogy az idegrendszeri éréshez szükséges alapvető mozgásminták kialakuljanak. A testi növekedés és a pszichológiai fejlődés biológiai mechanizmusok, melyek az érés által irányítottak, a környezetnek másodlagos szerepe van az alakulásukban. Ideális esetben az egyensúly fejlődése spontán érés hatására megy végbe, az anya ringató mozgásával, illetve a külső környezet felfedezésével, amikor a gyermek különböző intenzitású és irányú mozgást végez. E felfogás szerint a fejlődéshez meg kell adnunk bizonyos alap- 
vető feltételeket, a többi úgymond jön magától. Azonban, ha az egyensúlyi rendszer fejlődésében zavar keletkezik, az ősi, primitív reflexek nem fognak leépülni. Ez kihat a magasabb szintű funkciók fejlődésére, melyek akadályozzák az idegrendszer zavartalan érési folyamatát.

Hirtz és munkatársai (2004) szerint az egyensúlyozó képesség fejlődése óvodáskorban (3-7 éves kor között) olyan mértékü, amelyre a későbbi életszakaszokban már nincs példa. Az idegrendszer érettsége ebben az életkorban már 70-90\%-os fejlettséget mutat, ez pedig azt jelenti, hogy adottak a biológiai és pszichológiai feltételek az egyensúlyfejlesztéshez (Mészáros, 1990). A szerző szerint az egyensúlyozó képesség fejlődése az alábbi három szakaszra bontható. Az első időszak 4-8 éves kor között van, amikor csak lassú javulás figyelhető meg, a relatív fejlettség 10-25\% között van. A második periódus 8-12 éves kor közé esik, ahol csaknem 90\% körül jár a fejlettségi szint. A teljesítményváltozás sebességcsúcsa 8-10 éves kor között van. Ebben a szakaszban a fiúk és a lányok teljesítményének korosztályonként vett átlagai hasonlók. A harmadik fázisra pedig már jellemzőek a nemek közötti különbségek, ami 12-13 éves kortól figyelhető meg.

Az óvodások dinamikus egyensúlyfejlesztésével számos kutató foglalkozott. A szakemberek többnyire csak a vonalon és a gerendán való járást alkalmazták (Kasuga et al., 2012). Wang \& Chang (1997) megállapította, hogy a 3-6 éves Down-szindrómával és mentális retardációval rendelkező gyermekek gerendán végrehajtott járás teszt eredményei javultak az ugrásokból és szökdelésekből álló intervenció hatására. Bar-Haim \& Bart (2006) a BruninksOseretsky-féle mozgásprogramot alkalmazta az 5-6 éves óvodásoknál és pozitív szignifikáns összefüggést talált a gyermekek egyensúlyozó képessége és szociális játéktevékenységei között. Niederer és munkatársai (2011) arra a következtetésre jutottak, hogy a gerendán történő egyensúlyozás pozitívan hat a gyermekek munkamemóriájára. Giacalone \& Rarick (2010) 3-5 éves óvodásokkal folytatott vizsgálatából kiderült, hogy a gerenda szélessége jobban befolyásolta a teljesítményt, mint a lejtése. D’Hondt és munkatársai (2011) megállapították, hogy 5-7 éves korban nincs szignifikáns különbség a normál testtömegü és a túlsúlyos gyermekek gerendán végzett járásteljesítményei között. Viszont a 8-9 és a 10-12 éves korosztály esetében a normál testtömegű gyermekek jobb eredményt értek el a túlsúlyos társaiknál.

Az óvodáskor az emberi motoros viselkedés lényeges időszaka, mivel bizonyított tény, hogy ekkor történik számos alapvető motoros készség megalapozása (DeOreo \& Keogh, 1980; Ulrich \& Ulrich, 1985; Shumway-Cook \& McCollum, 1991; Gallahue \& Donnely, 2003). Tudvalévő, hogy az egyensúlyozó képesség mérése nagyban függ a mérés során alkalmazott feladattól és eszközöktől, ugyanakkor az egyik egyensúlyi feladatban elért magas érték nincs feltétlenül összefüggésben egy másik feladat során mért magas értékkel (Drowatzky \& Zuccato, 1967; Ulrich \& Ulrich, 1985; Tsigilis \& munkatársai, 2001; Shimada et al., 2003). Ebből az következik, hogy pár feladat teljesítésével nem kapunk átfogó képet a gyermek egyensúlyozó képességéről. 
Évek óta tartunk a Budai Tornász Műhelyben óvodáskorú és kisiskolás gyermekek számára szertorna alapú fejlesztő tornát. A 60 és 90 perces foglalkozások középpontjában a rugalmas felületü eszközök, valamint a fiú és a leány tornaszerek állnak, amelyek hosszú távú hatásai jelentősen kihatnak a gyermekek későbbi életére is. A foglalkozások differenciáltan zajlanak külön az óvodások (3-4 és 5-6 évesek), külön a kisiskolások (6-10 évesek) számára. Fontosnak tartjuk, hogy az egyensúly fejlesztésére már ebben az életszakaszban is kiemelt hangsúlyt fektessünk, hiszen e motoros képesség megfelelő müködése nélkül a gyermekek hétköznapi cselekvései folyamatos hátrányt szenvedhetnek. A foglalkozásokon az egyensúlyfejlesztés változatos módon, játékos formában jelenik meg.

Magyarországon ennek a területnek a feltérképezése igen csekély, ugyanakkor az egyensúlyozás rendkívül tág és nagyon gazdag kutatási teret nyújt.

\section{A vizsgálat célja}

A kutatásunkban a Budai Tornász Műhelyben tartott tornák észrevételeit, illetve a kiválasztott gyakorlatok egyensúlyra gyakorolt hatását szeretnénk ellenőrizni egy meglehetősen objektív teszttel. Azt szeretnénk bizonyítani, hogy a fejlesztés során felhasznált rugalmas és instabil eszközök mennyire fontosak az egyensúly fejlesztésében és megtartásában, valamint azt, hogy azoknak a gyerekeknek, akik részt vesznek a speciális fejlesztő foglalkozásokon, három hónap után mozgásuk rendezettebb és pontosabb lesz, valamint jobb teljesítményt fognak elérni az intervenciót követően a kiindulási szinthez képest. A tanulmányunkban szereplő mérések egy hosszabb, hat hónapos méréssorozat első állomását jelentik.

\section{A vizsgálat hipotézisei}

1. Feltételezzük, hogy az iskoláskorú gyermekek összességében jobb teljesítményt érnek el a vizsgálat során, mint az óvodáskorú társaik.

2. Feltételezzük, hogy a második mérés során a vizsgálati csoportba tartozó 5-6 éves óvodások és a 7-10 éves kisiskolások jobb eredményt érnek el a három hónapos intervenció hatására a kontrollcsoportban résztvevő társaikhoz képest.

3. Feltételezzük, hogy összességében a vizsgált személyek emelt gerendán rosszabb eredményt érnek el, mint talajgerendán.

\section{A vizsgálat módszerei}

\section{Vizsgálati protokoll}

A kutatásunkban összesen 4 csoportot vizsgáltunk: 2 óvodás (5-6 évesek), illetve 2 iskolás (6-10 évesek) csoportot. Mind az óvodás, mind az iskolás alanyok közül 1-1 csoport vizsgálati csoportként vett részt egy három hóna- 
pos, heti $2 \times 60$ perces szenzomotoros fejlesztő tornán. A másik két csoport (kontrollcsoport) az óvoda testnevelési programjának és a mindennapos testnevelésnek megfelelően vett részt a mozgásfejlesztésben.

\section{Vizsgálati személyek}

A kutatásunkban résztvevő gyermekeket két csoportba osztottuk: vizsgálati és kontrollcsoportra. A vizsgálati csoportba tartoznak azok az óvodás, illetve kisiskolás gyermekek ( $\mathrm{VO}=$ vizsgálati óvodás csoport; $\mathrm{VI}=$ vizsgálati iskolás csoport), akik hetente $2 \times 60$ perces, a Budai Tornász Mühely által tartott torna foglalkozásokon vesznek részt, azon belül is az 5-6 éves óvodás, valamint a 6-10 éves iskolás korosztály. A kontrollcsoportokat $(\mathrm{KO}=$ kontroll óvodás csoport; $\mathrm{KI}=$ kontroll iskolás csoport) pedig olyan velük egykorú óvodás, valamint kisiskolás gyermekek alkotják, akik nem vesznek részt ezeken a fejlesztő tornákon. Az óvodás kontrollcsoportot az I. kerületi Nyárs Utcai Óvoda középső csoportos gyermekei alkotják, az iskolás kontrollcsoportot pedig a VIII. kerületben található Losonci Téri Általános Iskola 2., 3. és 4. osztályos tanulói közül egyszerű véletlen mintavételi eljárással válogattuk ki.

A vizsgálati csoportban az óvodás gyermekek száma 17 fö (11 fiú, 6 lány), a kisiskolás gyermekek száma 26 fő (13 fiú, 13 lány). A kontrollcsoportban az óvodás korosztályt tekintve hasonló létszámmal dolgoztunk együtt, mint a vizsgálati csoportban: itt a vizsgálati személyek száma 19 fö (10 fiú, 9 lány). A kontrollcsoportban szereplő alsó tagozatos kisiskolások létszáma pedig 15 fö (7 fiú, 8 lány) volt. A vizsgálati és a kontrollcsoportból is voltak olyan tanulók, akik előzetesen rendelkeztek más sportágból származó sportmúlttal.

\section{Dinamikus egyensúlypróbák (Fetz \& Kornexl, 1973)}

A gyermekek egyensúlyozó képességének a felmérésénél arra törekedtünk, hogy objektív módon, hiteles mérésekkel térképezzük fel az alanyok kiindulási, majd a három hónappal későbbi teljesítményét. A test dinamikus egyensúlyának a vizsgálatára talajgerendán, illetve emelt gerendán dinamikus egyensúlypróbákat végeztünk el (1. és 2 . ábra). A felméréseket a sérülések elkerülése érdekében mind a vizsgálati, mind a kontrollcsoportnál mindig alapos, 10-15 perces bemelegítés előzte meg. A teszt felmérése előtt minden gyermeknek lehetősége volt előzetes gyakorlásra mindkét eszközön.

\section{Egyensúlyozó járás talajgerendán nyitott szemmel}

- Alkalmazási terület: a dinamikus egyensúlyozó képesség mérése.

- Szükséges eszközök: $1 \mathrm{db}$ stopperóra, $1 \mathrm{db} 10 \mathrm{~cm}$ magas, $10 \mathrm{~cm}$ széles, $5 \mathrm{~m}$ hosszú talajgerenda, középen kijelölt 2 m-es szakasszal.

- Feladat végrehajtása: a vizsgálati személynek a lehető legnagyobb távolságot kell megtennie a talajgerendán $45 \mathrm{sec}$ alatt úgy, hogy a kijelölt $2 \mathrm{~m}$-es szakaszon túl mindig visszafordul az ellenkező irányba. A feladat közben karral és 
lábbal szabad egyensúlyozni és mezítláb, nyitott szemmel kell végrehajtani a gyakorlatot. A kísérletet befejezettnek kell tekinteni abban az esetben, ha 45 másodpercen belül a vizsgálati személy lelép a gerendáról. A vizsgálati személynek egy próbakísérlete és két mért kísérlete van a gyakorlat végrehajtására. A vizsgálati személy feláll a jelzés mögé, majd „rajt” vezényszóra megkezdi a gyakorlatot, a stoppert pedig ekkor indítjuk el.

- Feladat értékelése: a két kísérlet összeredménye (az egyensúlyozás öszsztávolsága 0,5 m-es pontossággal, valamint az egyensúlyozás összideje 1 másodperces pontossággal).

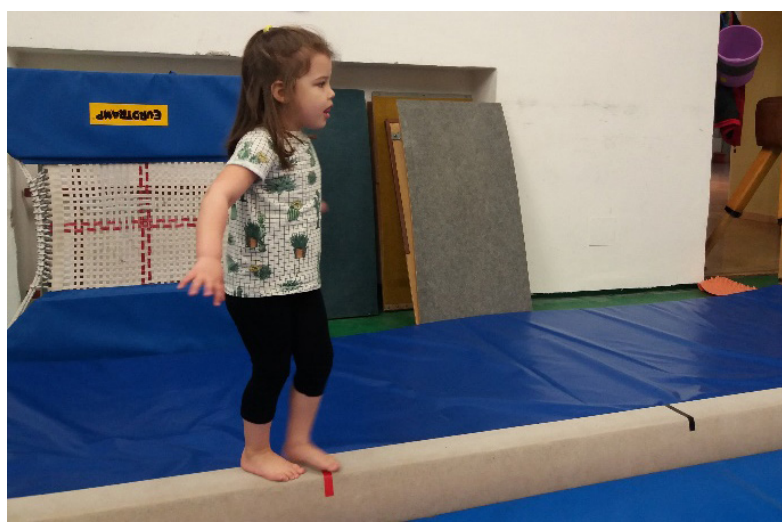

1. ábra

Egyensúlyozó járás talajgerendán.

Egyensúlyozó járás emelt gerendán nyitott szemmel

- Alkalmazási terület: a dinamikus egyensúlyozó képesség mérése.

- Szükséges eszközök: 1 db stopperóra, 1 db $10 \mathrm{~cm}$ magas, $10 \mathrm{~cm}$ széles, $5 \mathrm{~m}$ hosszú talajgerenda, középen kijelölt $2 \mathrm{~m}$-es szakasszal, $2 \mathrm{db} 25 \mathrm{~cm}$ magas zsámoly.

- Feladat végrehajtása és értékelése: ugyanúgy történik, mint a talajgerenda esetében. 
Három hónapos szenzomotoros torna hatása az óvodások és kisiskolások egyensúlyozó képességére

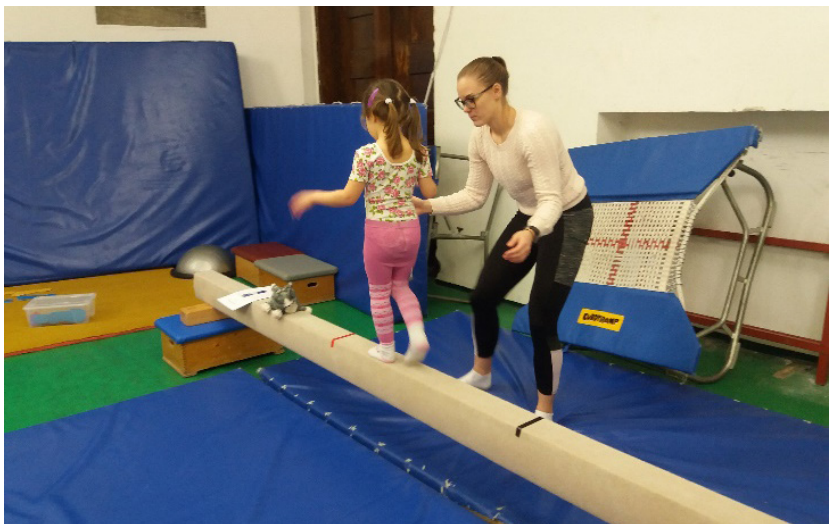

2. ábra

Egyensúlyozó járás emelt gerendán.

\section{Három hónapos szenzomotoros torna}

A három hónapos szenzomotoros torna a Budapesti Egyetemi Katolikus Gimnázium és Kollégium jól felszerelt tornatermében zajlott. A tornafoglalkozások során kiemelt hangsúlyt fektettünk az alapvető természetes mozgásformák (járás, futás, ugrás, kúszás, mászás stb.), illetve a koordinációs képességek, főként az egyensúlyérzék fejlesztésére. (3. ábra)

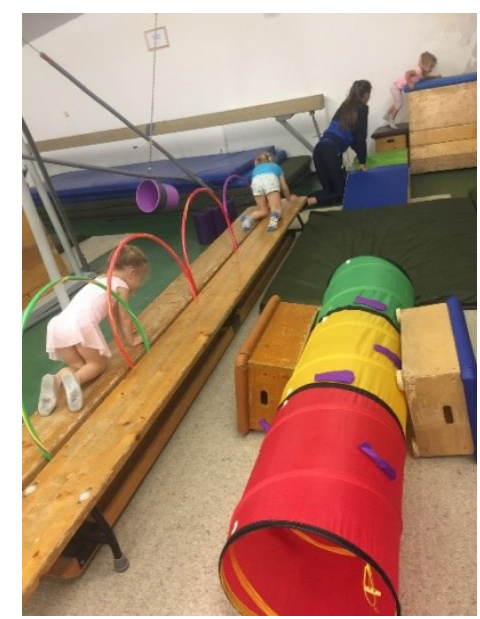

3. ábra

A szenzomotoros torna természetes mozgásokból álló akadálypályája. 
A vizsgálati csoportban szereplő óvodás, illetve kisiskolás gyermekek már a felmérés előtt is jártak hetente egyszer vagy kétszer szertorna alapú mozgásfejlesztő tornára, ezért számukra nem volt idegen a sok rugalmas felületü és instabil tornaeszköz (gumiasztal, BOSU egyensúly tréner, lépegető tüskés félgömb, Dynair egyensúlyozó párna). Ezek az eszközök álltak a tornáink középpontjában, és megfelelőnek bizonyultak az egyensúlyozó képesség fejlesztésére. Igyekeztünk ezeket az eszközöket a lehető legváltozatosabb módon felhasználni és beépíteni játékos akadálypályákba újabb és újabb gyakorlatok által. (4. ábra) Többnyire az alábbi, vidám nevekkel ellátott gyakorlatokat alkalmaztuk az egyensúlyérzék fejlesztésére:

- „Mocsárjárás”: talajra helyezett dynair ülőpárnákon egyensúlyozó járás különböző irányokba (előre, oldalt, hátra).

- „Mérlegállás” és „lebegőállás”: talajra helyezett dynair ülőpárnákon statikus egyensúlyi feladatok egy lábon.

- „Térdelések” és „térdelőtámaszok”: talajra helyezett dynair ülőpárnákon statikus egyensúlyi feladatok, térdtámasszal az ülőpárnán.

- „Szuperman” és „banán”: talajra helyezett BOSU egyensúlyozó félgömbön statikus egyensúlyi feladatok hanyatt- és hasonfekvésben.

- „Pörgettyü”: talajra helyezett BOSU egyensúlyozó félgömbön statikus egyensúlyi feladatok zsugorülésben.

- „Olló” és „bomba”: gumiasztalon szökdelés közben lábterpesztések oldalt és haránthelyzetben, valamint térdemelések előre.

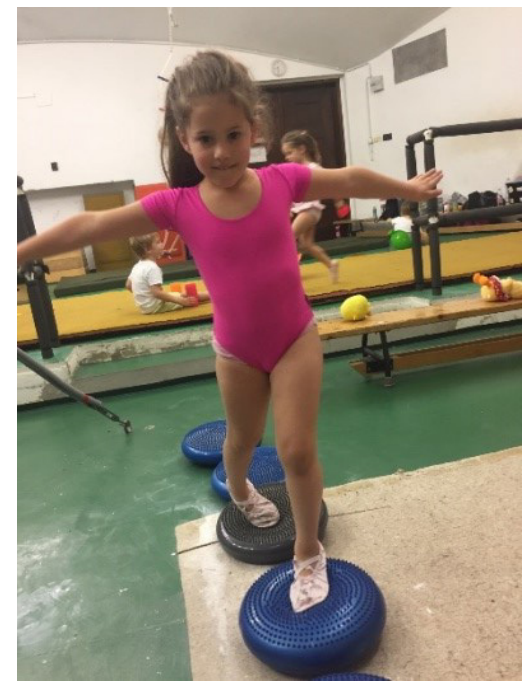

4. ábra

A szenzomotoros torna „mocsárjárás” feladata. 
A foglalkozások során figyeltünk arra, hogy minden feladatot az adott életkorhoz igazodva építsünk fel. A fokozatosság elvét betartva a könnyütől haladtunk a nehezebb felé, az egyszerütől a bonyolultabb felé. Az óvodás korosztály számára kihívást jelentett minden olyan gyakorlat, amelyben instabil eszközön történő járás szerepelt. Azt vettük észre, hogy a félelemérzetük ebben a korban még igen alacsony, ezért különösen ügyeltünk arra, hogy minden nehézséggel járó gyakorlatot tornaszőnyeggel rakjunk körbe, hogy balesetveszély, illetve sérülés ne alakulhasson ki.

\section{Alkalmazott statisztikai módszerek}

Elsőként a vizsgálati személyek különböző méréseken elért eredményeinek leíró statisztikáit (esetszám, átlag, szórás) és a változók közötti Pearson-korrelációkat számítottuk ki. Majd a próbák elvégzéséhez szükséges előfeltevések tesztelésére a normalitás és a szóráshomogenitás vizsgálatokat végeztük el. A vizsgálati csoportok eredményei közötti eltéréseket külön az 1. mérésen és külön a 2. mérésen belül varianciaanalízissel vizsgáltuk, a Post hoc tesztek közül pedig szóráshomogenitás teljesülése estén az LSD-t, nem teljesülése esetén a Tamhane's T2 tesztet alkalmaztuk. Ezt követően elemeztük a két mérés közötti eltéréseket is páros t-próbákkal. Azokban az esetekben, ahol a feltételek nem teljesülnek, a fent említett vizsgálatok nem parametrikus párjait alkalmaztuk, a méréseken belüli csoportok összehasonlítására MannWhitney U-próbát, a két mérés közötti teljesítménybeli különbségeket pedig Wilcoxon-próbával teszteltük. Végezetül összehasonlítottuk a vizsgálati személyek különböző gerenda típusokon elért teljesítményeit is. Az eredményeket $\mathrm{p}=0,05$-ös és esetenként $\mathrm{p}=0,01$-es szignifikanciaszint mellett is vizsgáltuk. Az elemzés az IBM SPSS Statistics 22 szoftver segítségével készült.

\section{Eredmények}

\section{Együttjárások vizsgálata}

Az első mérések során kapott eredmények korrelációs vizsgálatai közül négy esetben tapasztaltunk szignifikáns mértékủ együttjárást a vizsgált változók között. (1. táblázat) 
1. táblázat

Változók közötti Pearson-korrelációk.

\begin{tabular}{|c|c|c|c|c|c|c|}
\hline & \multicolumn{2}{|c|}{ Talajgerenda idő (sec) } & \multicolumn{2}{|c|}{ Emelt gerenda táv (m) } & \multicolumn{2}{|c|}{$\begin{array}{l}\text { Emelt gerenda idő } \\
(\mathrm{sec})\end{array}$} \\
\hline & 1. mérés & 2. mérés & 1. mérés & 2. mérés & 1. mérés & 2. mérés \\
\hline $\begin{array}{l}\text { Talajgeren- } \\
\text { da táv (m) }\end{array}$ & $\begin{array}{l}r=, 465^{* * *} \\
p=, 000\end{array}$ & $\begin{array}{l}r=, 380 * \% \\
p=, 001\end{array}$ & $\begin{array}{l}\mathrm{r}=, 819 \% \\
\mathrm{p}=, 000\end{array}$ & $\begin{array}{l}r=, 809 * \% \\
p=, 000\end{array}$ & $\begin{array}{l}r=, 258 \% \\
p=, 023\end{array}$ & $\begin{array}{l}r=-, 037 \\
p=, 751\end{array}$ \\
\hline $\begin{array}{l}\text { Talajgeren- } \\
\text { da idő (sec) }\end{array}$ & & & $\begin{array}{l}r=, 134 \\
p=, 244\end{array}$ & $\begin{array}{l}r=, 025 \\
p=, 828\end{array}$ & $\begin{array}{l}r=, 216 \\
p=, 059\end{array}$ & $\begin{array}{l}r=, 268 \% \\
p=, 019\end{array}$ \\
\hline $\begin{array}{l}\text { Emelt ge- } \\
\text { renda táv } \\
(\mathrm{m})\end{array}$ & & & & & $\begin{array}{l}r=, 355^{* * *} \\
p=, 002\end{array}$ & $\begin{array}{l}r=, 147 \\
p=, 201\end{array}$ \\
\hline
\end{tabular}

**. Szignifikáns korreláció $\mathrm{p}=$ 0,01-es szignifikanciaszint mellett, *. Szignifikáns korreláció $\mathrm{p}=0,05$-ös szignifikanciaszint mellett

A talajgerenda távolság és talajgerenda időeredmények között $(\mathrm{r}=0,465$; $\mathrm{p}<0,001)$ szintúgy, akárcsak az emelt gerenda távolság és emelt gerenda időeredmények között $(r=0,355 ; p=0,002)$ közepesnél valamivel gyengébb, pozitív korrelációs kapcsolatot figyelhetünk meg 0,01-es szignifikancia szint mellett. Az eredmények nem okoznak nagy meglepetést, hiszen a gerendákon hosszabb távolságot megtévő gyerekek időeredményeiben is többé-kevésbé meg kell nyilvánulnia annak, hogy ők várhatóan hosszabb időt is töltöttek a gerendákon egyensúlyozva. Érdekesebb eredmény azonban, hogy a talajgerenda távolság és az emelt gerenda távolság változók között viszont jelentősen erős pozitív korreláció $(\mathrm{r}=0,819 ; \mathrm{p}<0,001)$ van jelen. Tehát szignifikáns az összefüggés, hogy azok a gyerekek, akik a talajgerendán vagy az emelt gerendán hosszabb távolságokat teljesítettek, a másik gerenda gyakorlaton is hosszabb távolságokat tudtak megtenni. Ugyancsak érdekes azonban, hogy a talajgerenda távolság és az emelt gerenda időeredmények között $(\mathrm{r}=0,258$; $\mathrm{p}=0,023$ ) is megfigyelhető gyenge pozitív korreláció, tehát a talajgerendán hosszabb távolságot megtévő gyerekekhez valamivel magasabb emelt gerendán való egyensúlyozási idők is tartoznak, azonban ennek fordítottja nem teljesül. Tehát az emelt gerendán hosszabb távolságot megtévő gyerekekhez nem tartoznak szignifikánsan magasabb talajgerendán való egyensúlyozási idők.

Ezek után a második mérések alkalmával kapott eredmények közötti korrelációs vizsgálatok már csak három esetben mutatnak szignifikáns együttjárásokat a vizsgált változók között. (1. táblázat) A talajgerenda távolság és talajgerenda időeredmények között az előzőnél ugyan gyengébb, de ösz- 
szességében továbbra is közepesnél gyengébb $(\mathrm{r}=0,380 ; \mathrm{p}=0,001)$ pozitív korreláció figyelhető meg, azonban ez a jelenség az emelt gerenda távolság és emelt gerenda időeredmények között már nem áll fenn. Tehát míg a talajgerenda mérések során a második alkalommal is megfigyelhetö, hogy a gerendán hosszabb távot megtévő gyerekek eredményeihez szignifikánsan magasabb talajgerenda időeredmények is tartoznak, addig az emelt gerendán mért tesztek során a hosszabb vagy rövidebb távolságokat megtévő gyerekek időeredményeiben már nem figyelhető meg ez az eltérés. A talajgerenda távolság és az emelt gerenda távolság változók közötti jelentősen erős pozitív korreláció $(\mathrm{r}=0,809 ; \mathrm{p}<0,001)$ viszont a második mérések alkalmával továbbra is változatlanul érzékelhető. Sőt, a második mérések alkalmával a talajgerenda idő és az emelt gerenda idő változók között is megfigyelhetünk gyenge pozitív korrelációt $(\mathrm{r}=0,268 ; \mathrm{p}=0,019) \mathrm{p}=0,05$-ös szignifikancia szint mellett vizsgálva az eredményeket.

\section{Első méréseken belüli összehasonlitás}

Első körben a csoportok első mérésein elért távolság majd idő eredményeit vetettük össze, ezt követően vizsgáltuk a második mérésen elért eredmények közötti eltéréseket. A talajgerenda értékek leíró statisztikái a 2. táblázatban, az emelt gerendán elért eredmények leíró statisztikái a 3. táblázatban láthatók. Az adatokat a jobb láthatóság és értelmezhetőség miatt diagramos formában is ábrázoltuk a talajgerenda (5. és 6. ábra), illetve az emelt gerenda (7. és 8. ábra) viszonylatában.

A normalitási és a szóráshomogenitási előfeltételek a vizsgálatok alapján mindkét gerendatípus tekintetében a távolság eredmények esetében teljesülnek, azonban az időeredmények esetében nem, ezért a távolságot mérő változókat varianciaanalízissel, az időeredményeket mérő változókat viszont a nemparametrikus Mann-Whitney U próbát alkalmazva hasonlítottuk össze.

2. táblázat

Talajgerenda mérések eredményeinek vizsgálati csoportonként bontott leíró statisztikái

\begin{tabular}{|c|c|c|c|c|}
\hline \multirow{2}{*}{} & \multicolumn{2}{|c|}{ távolság $(\mathbf{m})$} & \multicolumn{2}{c|}{ idő (sec) } \\
\cline { 2 - 5 } & $\begin{array}{c}\text { 1.mérés } \\
\text { (átlag } \pm \text { szórás) }\end{array}$ & $\begin{array}{c}\text { 2.mérés } \\
\text { (átlag } \pm \text { szórás) }\end{array}$ & $\begin{array}{c}\text { 1.mérés } \\
\text { (átlag } \pm \text { szórás) }\end{array}$ & $\begin{array}{c}\text { 2.mérés } \\
\text { (átlag } \pm \text { szórás) }\end{array}$ \\
\hline $\mathrm{VO}(\mathrm{n}=17)$ & $24,94 \pm 8,67$ & $32,94 \pm 9,97$ & $75,47 \pm 15,79$ & $81,35 \pm 13,48$ \\
\hline $\mathrm{KO}(\mathrm{n}=19)$ & $21,53 \pm 7,06$ & $27,05 \pm 7,86$ & $71 \pm 20,47$ & $85,95 \pm 10,1$ \\
\hline $\mathrm{VI}(\mathrm{n}=26)$ & $44,35 \pm 15,22$ & $49,88 \pm 10,33$ & $75,65 \pm 21,83$ & $80,92 \pm 15,46$ \\
\hline $\mathrm{KI}(\mathrm{n}=15)$ & $28,8 \pm 10,35$ & $33,67 \pm 11,31$ & $82,87 \pm 12,75$ & $83,67 \pm 16,73$ \\
\hline
\end{tabular}


3. táblázat

Emelt gerenda mérések eredményeinek vizsgálati csoportonként bontott leíró statisztikái.

\begin{tabular}{|l|c|c|c|c|}
\hline \multirow{2}{*}{} & \multicolumn{2}{|c|}{ távolság $(\mathbf{m})$} & \multicolumn{2}{c|}{ idő (sec) } \\
\cline { 2 - 5 } & $\begin{array}{c}\text { 1.mérés } \\
\text { (átlag } \pm \text { szórás) }\end{array}$ & $\begin{array}{c}\text { 2.mérés } \\
\text { (átlag } \pm \text { szórás) }\end{array}$ & $\begin{array}{c}\text { 1.mérés } \\
\text { (átlag } \pm \text { szórás) }\end{array}$ & $\begin{array}{c}\text { 2.mérés } \\
\text { (átlag } \pm \text { szórás) }\end{array}$ \\
\hline VO $(\mathrm{n}=17)$ & $23,71 \pm 8,04$ & $30,53 \pm 8,6$ & $76,65 \pm 16,18$ & $88,53 \pm 6,06$ \\
\hline KO $(\mathrm{n}=19)$ & $18,95 \pm 5,35$ & $22,95 \pm 5,85$ & $85 \pm 11,67$ & $88,84 \pm 3,53$ \\
\hline VI $(\mathrm{n}=26)$ & $47,96 \pm 9,98$ & $53,04 \pm 8,7$ & $87,31 \pm 8,94$ & $87 \pm 7,74$ \\
\hline KI $(\mathrm{n}=15)$ & $27,87 \pm 10,97$ & $26,8 \pm 10,43$ & $88,33 \pm 5,68$ & $84,2 \pm 12,66$ \\
\hline
\end{tabular}

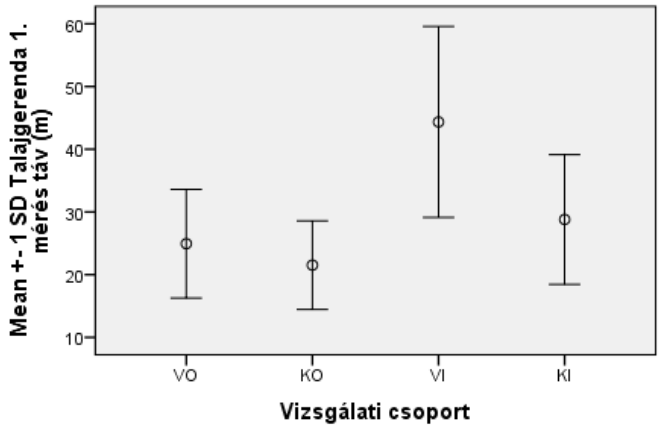

5. ábra

A négy vizsgálati csoport talajgerenda 1. mérés távolság eredményei (méterben).

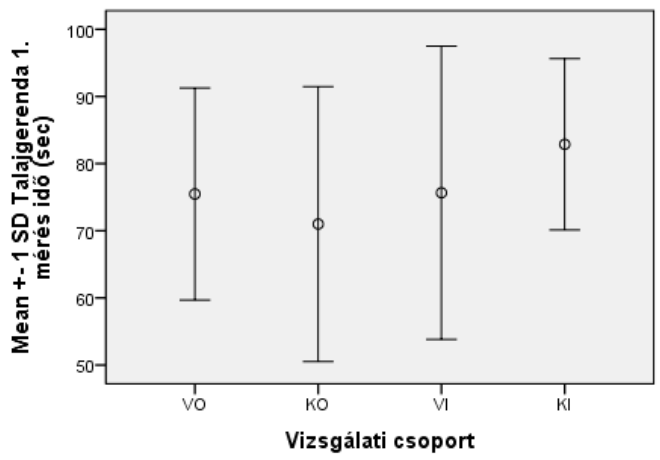

6. ábra

A négy vizsgálati csoport talajgerenda 1. mérés idöeredményei (másodpercben). 
Három hónapos szenzomotoros torna hatása az óvodások és kisiskolások egyensúlyozó képességére

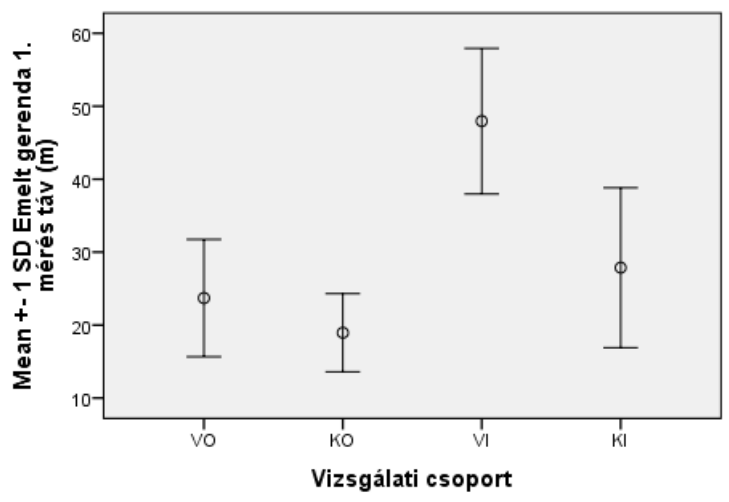

7. ábra

A négy vizsgálati csoport emelt gerenda 1. mérés távolság eredményei(méterben).

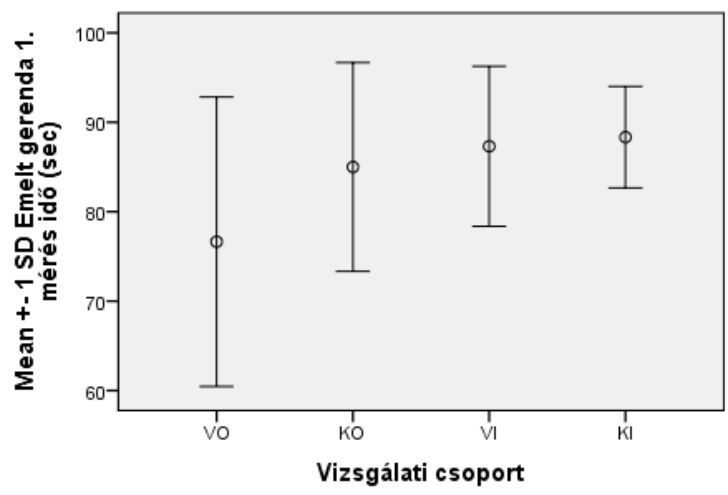

8. ábra

A négy vizsgálati csoport emelt gerenda 1. mérés idöeredményei (másodpercben).

A 4. táblázatban összesített eredmények alapján látható, hogy a Leveneteszt a csoportok szórásai között szignifikáns eltérést a gerenda gyakorlatok első mérési eredményei esetén mutat. Ezért ezeknél a méréseknél a robusztusabb Welch-próba eredménye és a hozzá tartozó szignifikancia a mérvadó, míg a második mérések eredményei esetén, ahol teljesül a szóráshomogenitás ott az F-próbához tartozó szignifikancia informál a teszt eredményéről. Szemügyre véve a próbákhoz tartozó szignifikanciaszinteket, az értékek mindegyik mérés esetén szignifikáns különbséget jeleznek a csoportok átlagos távolság eredményei között. 
Arra, hogy kiderüljön, pontosan melyik csoportok teljesítményei tértek el egymástól statisztikailag is szignifikáns mértékben, a fejlesztő torna előtti mérések eredményein végzett Tamhane’s T2 post hoc tesztek adnak választ, melyeknek eredményei az 5. táblázatban láthatók.

4. táblázat

ANOVA vagy Welch-próba eredményei csoportok közötti eltérések vizsgálatára

\begin{tabular}{|l|c|c|c|c|c|c|}
\hline & \multicolumn{2}{|c|}{$\begin{array}{c}\text { Szóráshomogeni- } \\
\text { tás vizsgálat }\end{array}$} & \multicolumn{2}{|c|}{ ANOVA } & \multicolumn{2}{c|}{ Welch-próba } \\
\hline & $\begin{array}{c}\text { Levene- } \\
\text { teszt }\end{array}$ & Sig. & F & Sig. & $\begin{array}{c}\text { Welch-pró- } \\
\text { ba }\end{array}$ & Sig. \\
\hline $\begin{array}{l}\text { Talajgerenda 1. mé- } \\
\text { rés táv (m) }\end{array}$ & $4,634^{*}$ &, 005 & - & - & $14,96^{*}$ &, 000 \\
\hline $\begin{array}{l}\text { Emelt gerenda 1. mé- } \\
\text { rés táv (m) }\end{array}$ & $2,819^{*}$ &, 045 & - & - & $51,56^{*}$ &, 000 \\
\hline $\begin{array}{l}\text { Talajgerenda 2. mé- } \\
\text { rés táv (m) }\end{array}$ & 0,682 &, 566 & $22,545^{*}$ &, 000 & - & - \\
\hline $\begin{array}{l}\text { Emelt gerenda 2. mé- } \\
\text { rés táv (m) }\end{array}$ & 0,810 &, 492 & $58,526^{*}$ &, 000 & - & - \\
\hline
\end{tabular}

*Szignifikanciaszint $\mathrm{p}=0.05$

Az eredmények azonos módon alakultak a különböző gerendákon végzett gyakorlatok során, ugyanis mindkét feladatban az iskolás vizsgálati csoport teljesített a legjobban, méghozzá statisztikailag is szignifikánsan hosszabb távolságokat tudtak megtenni minden másik csoporthoz képest. A talajgerenda gyakorlaton az iskolás kontrollcsoporthoz képest átlagosan 15,55 méterrel, a vizsgálati óvodás csoportnál átlagosan 19,4 méterrel, az óvodás kontrollcsoport első teljesítményéhez képest pedig átlagosan 22,82 méterrel tudtak hosszabb távon egyensúlyozni. Az emelt gerenda gyakorlaton pedig az iskolás kontrollcsoporthoz képest átlagosan 20,1 méterrel, a vizsgálati óvodás csoportnál átlagosan 24,26 méterrel, az óvodás kontrollcsoporthoz képest pedig átlagosan 29 méterrel tettek meg hosszabb távolságokat. A többi csoport eredményei nem tértek el egymástól statisztikailag jelentős mértékben, tehát az óvodás csoportok távolság eredményei között az első mérések alkalmával nem volt számottevő különbség. 
Három hónapos szenzomotoros torna hatása az óvodások és kisiskolások egyensúlyozó képességére

5. táblázat

Első mérések távolság eredményein végzett Tamhane’s T2 post hoc tesztek

\begin{tabular}{|c|c|c|c|c|c|c|c|}
\hline \multirow{2}{*}{\multicolumn{2}{|c|}{ (I) Csoport }} & \multicolumn{3}{|c|}{ Talajgerenda } & \multicolumn{3}{|c|}{ Emelt gerenda } \\
\hline & & \multirow{2}{*}{$\begin{array}{c}\begin{array}{c}\text { Átlagok kö- } \\
\text { zötti eltérés } \\
\text { (I-J) }\end{array} \\
19,405^{*}\end{array}$} & \multirow{2}{*}{$\begin{array}{c}\text { SE } \\
3,651\end{array}$} & \multirow{2}{*}{$\begin{array}{l}\text { Sig. } \\
, 000\end{array}$} & \multirow{2}{*}{$\begin{array}{c}\text { Átlagok kö- } \\
\text { zötti eltérés } \\
\text { (I-J) }\end{array}$} & \multirow{2}{*}{$\begin{array}{c}\text { SE } \\
2,763\end{array}$} & \multirow{2}{*}{$\begin{array}{l}\text { Sig. } \\
, 000\end{array}$} \\
\hline \multirow{3}{*}{ VI } & $\mathrm{VO}$ & & & & & & \\
\hline & $\mathrm{KO}$ & $22,820^{*}$ & 3,396 & ,000 & $29,014 *$ & 2,310 & ,000 \\
\hline & KI & $15,546 \%$ & 4,005 & ,002 & $20,095^{*}$ & 3,442 & ,000 \\
\hline \multirow{2}{*}{ KI } & VO & 3,859 & 3,400 & ,844 & 4,161 & 3,438 & ,803 \\
\hline & $\mathrm{KO}$ & 7,274 & 3,125 & 161 & 8,919 & 3,086 & ,055 \\
\hline $\mathrm{VO}$ & $\mathrm{KO}$ & 3,415 & 2,655 & ,753 & 4,759 & 2,303 & ,258 \\
\hline
\end{tabular}

Az óvodás csoportok és az iskolás csoportok időeredményeinek összehasonlítására végzett Mann-Whitney U-próbák eredményei a 6. táblázatban láthatók. A próbákhoz tartozó szignifikanciák alapján 95\%-os megbízhatóság mellett vizsgálva, egyik mérés alkalmával egyik korosztály vizsgálati és kontrollcsoport értékei között sem volt szignifikáns különbség.

6. táblázat

Mann-Whitney U-próba óvodás (VO-KO) és iskolás (VI-KI) csoportok idő eredményei közötti eltérések vizsgálatára

\begin{tabular}{|l|c|c|c|c|c|c|}
\hline & \multicolumn{2}{|c|}{ VO-KO (n=36) } & \multicolumn{2}{c|}{ VI-KI (n=41) } \\
\hline & $\begin{array}{c}\text { Standardi- } \\
\text { zált Teszt } \\
\text { Statisztika }\end{array}$ & SE & Sig. & $\begin{array}{c}\text { Standardizált } \\
\text { Teszt Statisz- } \\
\text { tika }\end{array}$ & SE & Sig. \\
\hline $\begin{array}{l}\text { Talajgerenda 1. } \\
\text { mérés idő (sec) }\end{array}$ & $-0,51$ & 30,38 & 0,61 & 1,01 & 33,04 & 0,311 \\
\hline $\begin{array}{l}\text { Emelt gerenda 1. } \\
\text { mérés idő (sec) }\end{array}$ & 1,7 & 26,48 & 0,089 & $-0,12$ & 21 & 0,905 \\
\hline $\begin{array}{l}\text { Talajgerenda 2. } \\
\text { mérés idő (sec) }\end{array}$ & 1,23 & 24 & 0,219 & 0,53 & 31,89 & 0,594 \\
\hline $\begin{array}{l}\text { Emelt gerenda 2. } \\
\text { mérés idő (sec) }\end{array}$ & $-0,43$ & 15,13 & 0,667 & $-0,9$ & 25,56 & 0,368 \\
\hline
\end{tabular}




\section{Második méréseken belüli összehasonlítás}

A második talajgerenda mérés során az óvodás vizsgálati csoport (VO) átlagosan 32,94 \pm 9,97 métert tudott megtenni, átlagosan 81,35 \pm 13,48 másodperc gerendán való tartózkodás közben. (2. táblázat) Az óvodás kontrollcsoport $(\mathrm{KO})$ rövidebb távot, átlagosan csak 27,05 \pm 7,86 métert tudott egyensúlyozni, átlagosan 85,95 \pm 10,1 másodpercen keresztül. Az iskolás vizsgálati csoport (VI) eredménye szintén kiemelkedően magasabb, a második mérés alkalmával átlagosan már 49,88 \pm 10,33 métert tettek meg a talajgerendán, időeredményük pedig átlagosan $80,92 \pm 15,46$ másodperc volt. Az iskolás kontrollcsoport ehhez képest átlagosan csupán 33,67 \pm 11,31 métert teljesített, azonban 83,67 $\pm 16,73$ másodperc hosszan tartózkodtak a gerendán. Hasonlóan az 1. méréséhez, a négy vizsgálati csoport talajgerendán ( 9 . és 10. ábra), valamint emelt gerendán (11. és 12. ábra) a 2. mérésre teljesített távolság- és időeredményeit is diagramon ábrázoltuk.

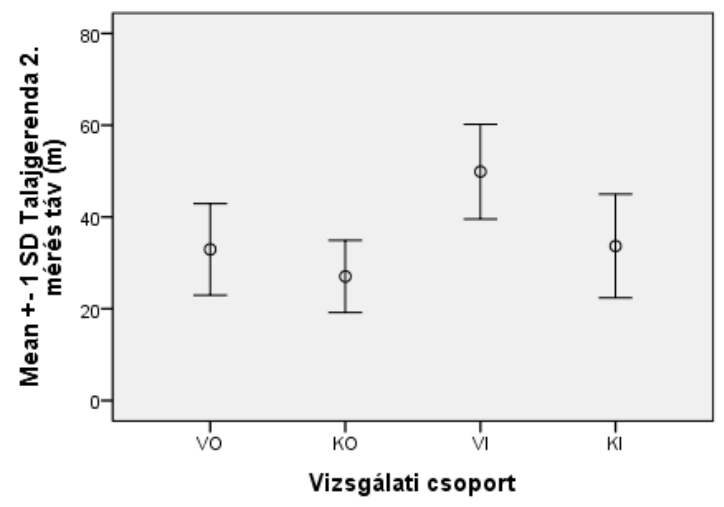

9. ábra:

A négy vizsgálati csoport talajgerenda 2. mérés távolság eredményei (méterben). 
Három hónapos szenzomotoros torna hatása az óvodások és kisiskolások egyensúlyozó képességére

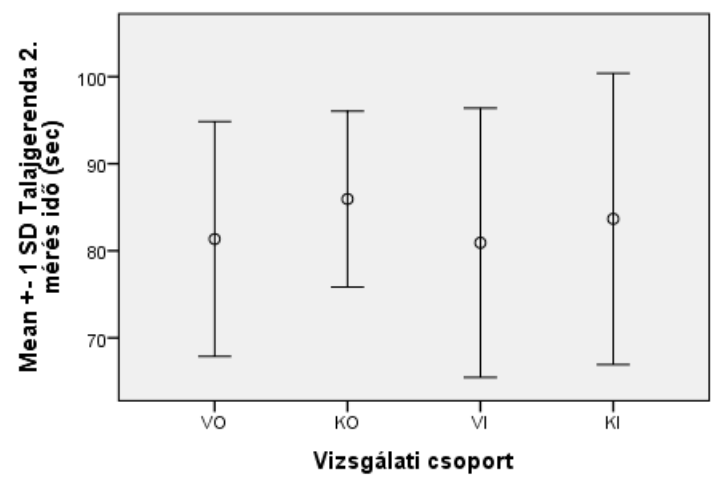

10. ábra

A négy vizsgálati csoport talajgerenda 2. mérés idöeredményei (másodpercben).

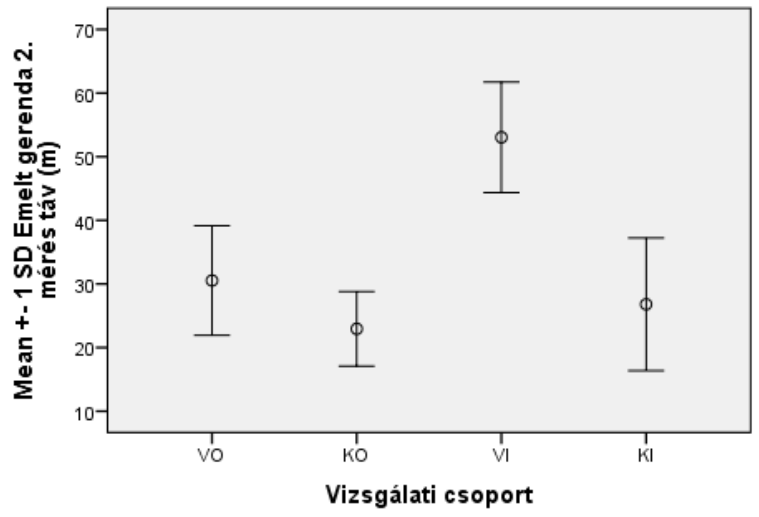

11. ábra

A négy vizsgálati csoport emelt gerenda 2. mérés távolság eredményei (méterben). 


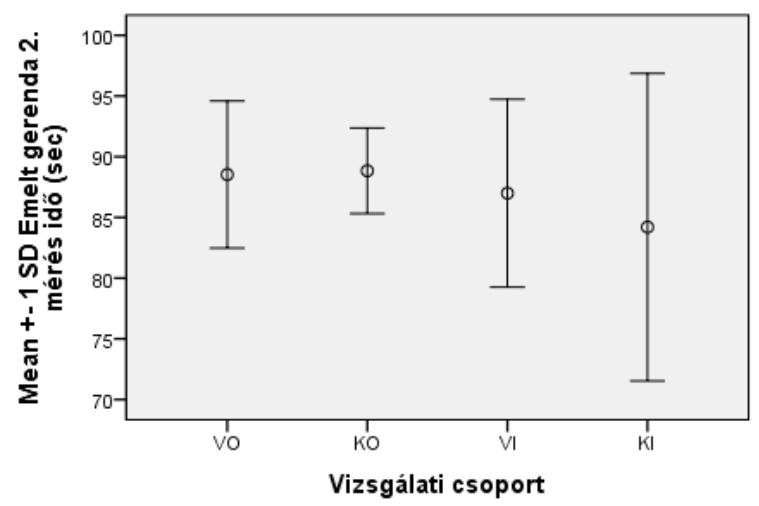

12. ábra

A négy vizsgálati csoport emelt gerenda 2. mérés idöeredményei (másodpercben).

Az emelt gerendán a második mérés alkalmával a VO csoport átlagosan 30,53 \pm 8,6 métert tett meg, átlagosan 88,53 \pm 6,06 másodperc gerendán való tartózkodás közben. (3. táblázat) $\mathrm{A} \mathrm{KO}$ csoport ennél rövidebb távot, átlagosan csak 22,95 \pm 5,85 métert tudott megtenni, átlagosan 88,84 \pm 3,53 másodpercen keresztül. A VI csoport megtett táv eredménye ennél a gerenda gyakorlatnál is jelentősen magasabb, az emelt gerendán átlagosan 53,04 \pm 8,7 métert tettek meg egyensúlyozva, időeredményük pedig átlagosan $87 \pm$ 7,74 másodperc volt. A KI csoport tagjai pedig átlagosan 26,8 $\pm 10,43$ métert tudtak megtenni, és átlagosan 84,2 $\pm 12,66$ másodperc hosszan tartózkodtak a gerendán.

A 4. táblázatban már megfigyelhettük, hogy az F-próbához tartozó szignifikanciák a második mérések alkalmával is szignifikáns különbséget jeleztek a csoportok átlagos távolság eredményei között, de hogy pontosan melyik csoportok között volt statisztikailag is számottevő differencia, azt a 7. táblázatban látható LSD post hoc tesztek szemléltetik. 
Három hónapos szenzomotoros torna hatása az óvodások és kisiskolások

7. táblázat

Második mérések távolság eredményein végzett LSD post hoc tesztek

\begin{tabular}{|l|c|c|c|c|c|c|c|}
\hline \multirow{2}{*}{} & \multicolumn{3}{|c|}{ Talajgerenda } & \multicolumn{3}{c|}{ Emelt gerenda } \\
\cline { 3 - 8 }$(\mathbf{3})$ Csoport & $\begin{array}{c}\text { Átlagok kö- } \\
\text { zötti eltérés } \\
(I-J)\end{array}$ & SE & Sig. & $\begin{array}{c}\text { Átlagok kö- } \\
\text { zötti eltérés } \\
(I-J)\end{array}$ & SE & Sig. \\
\hline \multirow{3}{*}{ VI } & VO & $16,943^{*}$ & 3,089 &, 000 & $22,509^{*}$ & 2,637 &, 000 \\
\cline { 2 - 8 } & KO & $22,832^{*}$ & 2,989 &, 000 & $30,091^{*}$ & 2,551 &, 000 \\
\cline { 2 - 8 } & KI & $16,218^{*}$ & 3,211 &, 000 & $26,238^{*}$ & 2,741 &, 000 \\
\hline \multirow{2}{*}{ KI } & VO & 0,725 & 3,508 &, 837 & $-3,729$ & 2,995 &, 217 \\
\cline { 2 - 8 } & KO & 6,614 & 3,421 &, 057 & 3,853 & 2,920 &, 191 \\
\hline \multirow{2}{*}{ VO } & KO & 5,889 & 3,306 &, 079 & $7,582^{*}$ & 2,822 &, 009 \\
\hline
\end{tabular}

Az eredmények már nem teljesen alakultak azonos módon a fejlesztő tornák után a különböző gerendatípuson végzett gyakorlatok során. A VI csoport viszont továbbra is mindkét feladatban kiemelkedően teljesített, a második alkalommal is statisztikailag szignifikánsan hosszabb távolságokat tudott megtenni a többi csoporthoz képest. A talajgerenda gyakorlaton a KI csoporthoz képest átlagosan 16,22 méterrel, a VO csoportnál viszont átlagosan már csak 16,94 méterrel, a KO csoport második méréséhez képest pedig átlagosan szinte azonosan az első méréskor megfigyelthez, 22,83 méterrel tudtak hosszabb távon egyensúlyozni. Az emelt gerenda gyakorlaton pedig az iskolás kontrollcsoporthoz képest átlagosan 26,24 méterrel, a vizsgálati óvodás csoportnál átlagosan 22,51 méterrel, az óvodás kontrollcsoporthoz képest pedig átlagosan 30,1 méterrel tettek meg hosszabb távolságokat. Érdekes azonban megfigyelni, hogy míg az óvodás csoportok távolság eredményei között az első mérések alkalmával még nem volt számottevő különbség, addig a fejlesztő torna utáni mérések során az óvodás vizsgálati csoport tagjai már szignifikánsan hosszabb (átlagosan 7,58 méter) távolságokat tudtak megtenni az óvodás kontrollcsoport tagjaihoz képest.

Az óvodás csoportok és az iskolás csoportok idő eredményei között a második mérés alkalmával sem volt szignifikáns különbség. (2. és 3. táblázat)

\section{A négy csoport elsö és második mérései közötti eltérések vizsgálata}

Mivel ahogy már említésre került a normalitási és a szóráshomogenitási elöfeltételek a vizsgálatok alapján a távolság eredmények esetében teljesülnek, azonban az időeredmények esetében nem, ezért távolság eredményeket páros mintás t-próbával (8. és 10. táblázat), az időeredményeket viszont a nemparametrikus Wilcoxon-próbát alkalmazva (9. és 11. táblázat) hasonlítottuk össze. 
8. táblázat

A négy csoport 1. és 2. talajgerenda távolság eredményei közötti eltérések vizsgálata páros mintás t-próbával

\begin{tabular}{|l|c|c|c|c|c|}
\hline \multirow{2}{*}{} & \multicolumn{2}{|c|}{ Páronkénti eltérések } & \multirow{2}{*}{ t } & df & p \\
\cline { 2 - 4 } & Átlag & Szórás & & & \\
\hline VO csoport 1. vs. 2. mérés (táv, m) & -8 & 5,9 & $-5,585$ & 16 &, $000^{*}$ \\
\hline KO csoport 1. vs. 2. mérés (táv, m) & $-5,53$ & 9 & $-2,689$ & 18 &, $015^{*}$ \\
\hline VI csoport 1. vs. 2. mérés (táv, m) & $-5,54$ & 9,6 & $-2,944$ & 25 &, $007^{*}$ \\
\hline KI csoport 1. vs. 2. mérés (táv, m) & $-4,87$ & 6 & $-3,118$ & 14 &, $008^{*}$ \\
\hline
\end{tabular}

9. táblázat

A négy csoport 1. és 2. talajgerenda idöeredményei közötti eltérések vizsgálata Wilcoxonpróbával

\begin{tabular}{|l|c|c|c|c|c|}
\hline & $\begin{array}{c}\text { Átlagok } \\
\text { közötti } \\
\text { eltérés }\end{array}$ & $\begin{array}{c}\text { Teszt } \\
\text { Statisz- } \\
\text { tika }\end{array}$ & $\begin{array}{c}\text { Stan- } \\
\text { dard } \\
\text { Error }\end{array}$ & $\begin{array}{c}\text { Standardi- } \\
\text { zált Teszt } \\
\text { Statisztika }\end{array}$ & p \\
\hline $\begin{array}{l}\text { VO csoport 1. vs. 2. mérés (idő, } \\
\text { sec) }\end{array}$ & $-5,88$ & 42 & 9,80 & 1,479 & 0,139 \\
\hline $\begin{array}{l}\text { KO csoport 1. vs. 2. mérés } \\
\text { (idő, sec) }\end{array}$ & $-14,95$ & 82 & 14,31 & 2,552 &, $011^{*}$ \\
\hline $\begin{array}{l}\text { VI csoport 1. vs. 2. mérés } \\
\text { (idő, sec) }\end{array}$ & $-5,27$ & 70 & 14,31 & 1,678 & 0,093 \\
\hline $\begin{array}{l}\text { KI csoport 1. vs. 2. mérés } \\
\text { (idő, sec) }\end{array}$ & $-0,80$ & 9 & 3,71 & 0,405 & 0,686 \\
\hline
\end{tabular}


Három hónapos szenzomotoros torna hatása az óvodások és kisiskolások egyensúlyozó képességére

10. táblázat

A négy csoport 1. és 2. emelt gerenda távolság eredményei közötti eltérések vizsgálata páros mintás t-próbával.

\begin{tabular}{|l|c|c|c|c|c|}
\hline \multirow{2}{*}{} & \multicolumn{2}{|c|}{ Páronkénti eltérések } & \multirow{2}{*}{ t } & df & p \\
\cline { 2 - 6 } & Átlag & Szórás & & & \\
\hline VO csoport 1. vs. 2. mérés (táv, m) & $-6,82$ & 3,3 & $-8,471$ & 16 &, $000^{*}$ \\
\hline KO csoport 1. vs. 2. mérés (táv, m) & -4 & 6,2 & $-2,808$ & 18 &, $012^{*}$ \\
\hline VI csoport 1. vs. 2. mérés (táv, m) & $-5,08$ & 8,4 & $-3,085$ & 25 &, $005^{*}$ \\
\hline KI csoport 1. vs. 2. mérés (táv, m) & 1,07 & 5,1 & 0,811 & 14 &, 431 \\
\hline
\end{tabular}

11. táblázat

A négy csoport 1. és 2. emelt gerenda idöeredményei közötti eltérések vizsgálata Wilcoxon-próbával.

\begin{tabular}{|l|c|c|c|c|c|}
\hline & $\begin{array}{c}\text { Átlagok } \\
\text { közötti } \\
\text { eltérés }\end{array}$ & $\begin{array}{c}\text { Teszt Sta- } \\
\text { tisztika }\end{array}$ & $\begin{array}{c}\text { Stan- } \\
\text { dard } \\
\text { Error }\end{array}$ & $\begin{array}{c}\text { Standardi- } \\
\text { zált Teszt } \\
\text { Statisztika }\end{array}$ & p \\
\hline $\begin{array}{l}\text { VO csoport 1. vs. 2. mérés } \\
\text { (idő, sec) }\end{array}$ & $-11,88$ & 36 & 7,13 & 2,524 &, $012^{*}$ \\
\hline $\begin{array}{l}\text { KO csoport 1. vs. 2. mé- } \\
\text { rés (idő, sec) }\end{array}$ & $-3,84$ & 16 & 4,77 & 1,153 & 0,249 \\
\hline $\begin{array}{l}\text { VI csoport 1. vs. 2. mé- } \\
\text { rés (idő, sec) }\end{array}$ & 0,31 & 5 & 2,74 & 0,000 & 1,000 \\
\hline $\begin{array}{l}\text { KI csoport 1. vs. 2. mé- } \\
\text { rés (idö, sec) }\end{array}$ & 4,13 & 3 & 3,71 & $-1,214$ & 0,225 \\
\hline
\end{tabular}

A négy csoport talaj- és emeltgerendán teljesített távolság- és időeredmények első és második mérése közötti különbségét diagramos formában is megjelenítettük. (13-16. ábrák) 


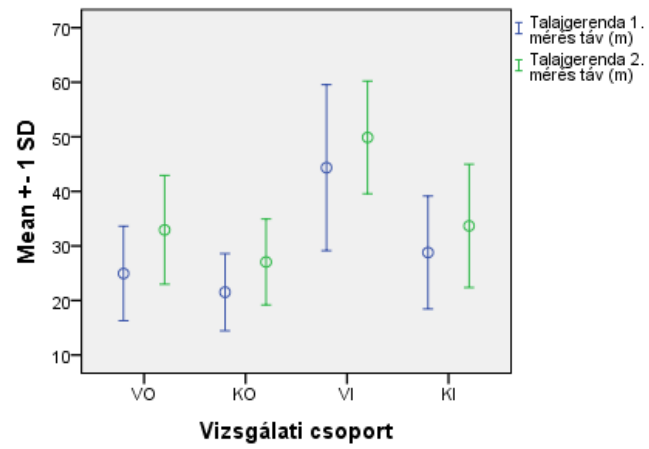

13. ábra

A négy vizsgálati csoport talajgerenda távolság 1. és 2. méréseinek összehasonlitása (méterben).

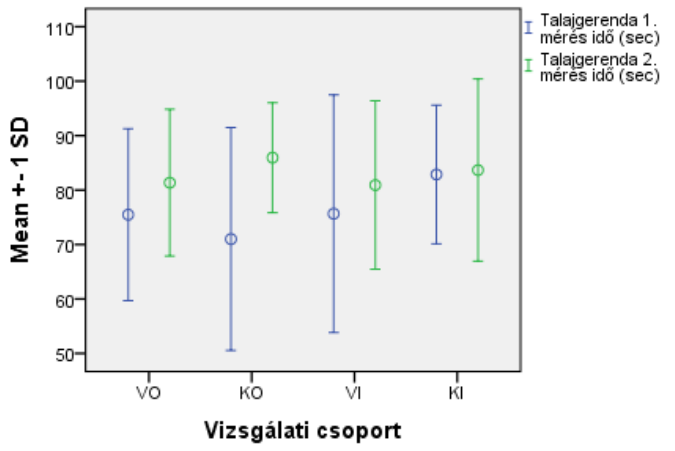

14. ábra

A négy vizsgálati csoport talajgerenda

1. és 2. idöméréseinek összehasonlitása (másodpercben). 
Három hónapos szenzomotoros torna hatása az óvodások és kisiskolások egyensúlyozó képességére

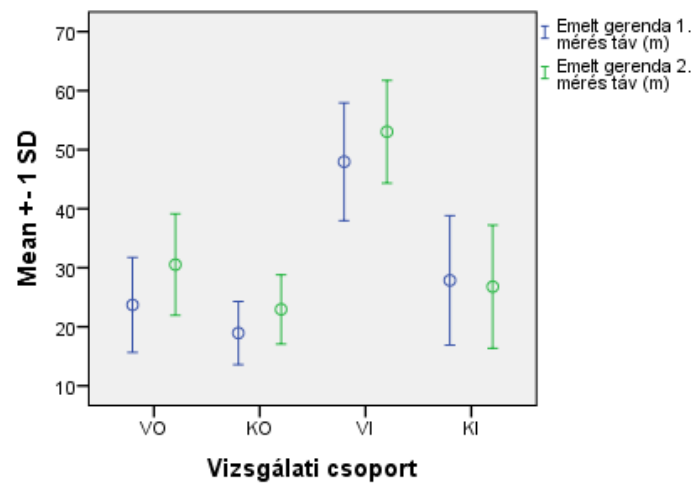

15. ábra

A négy vizsgálati csoport emelt gerenda távolság 1. és 2. méréseinek összehasonlítása (méterben)

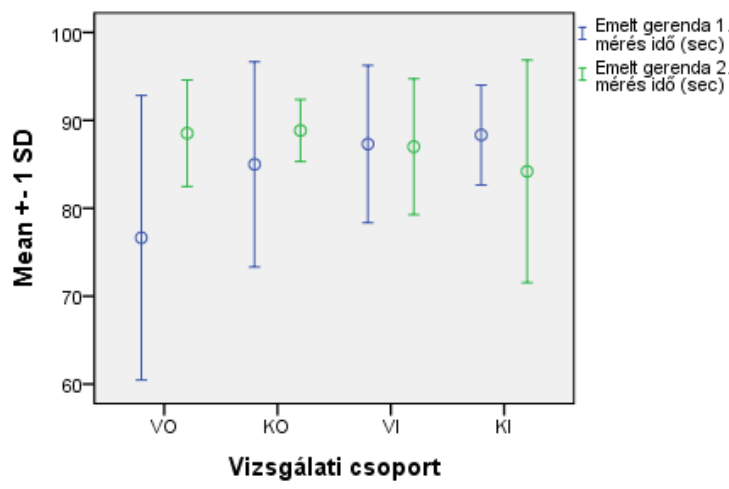

16. ábra

A négy vizsgálati csoport emelt gerenda idö

1. és 2. méréseinek összehasonlitása (másodpercben).

$V O$ - óvodás vizsgálati csoport

Első körben a VO csoport $(\mathrm{n}=17)$ 1. és 2. mérésének távolság és idő eredményeit vetettük össze mindkét gerendagyakorlat esetén. Az 1. és 2. mérés során kapott átlagos eredmények a 2. és 3. táblázatban figyelhetők meg. A talajgerendán megtett távolság eredmények között szignifikáns mértékü javulás tapasztalható $(\mathrm{t} 16=-5,585 ; \mathrm{p}<0,001)$, mivel a csoport tagjai átlagosan 8 \pm 5,9 méterrel hosszabb távolságokat tudtak megtenni a fejlesztő torna utáni 
mérés alkalmával. (8. táblázat) Az időeredmények az első alkalomhoz képest átlagosan 5,88 másodperccel növekedtek, de ez az eltérés statisztikailag nem szignifikáns mértékű. (9. táblázat)

Az emelt gerendán való teljesítmények között nagyon hasonló változások tapasztalhatók. A csoport által megtett távolságok a fejlesztő torna utáni mérésen átlagosan 6,82 \pm 3,3 méterrel voltak hosszabbak, ami szintén szignifikáns növekedés (t16 $=-8,471 ; \mathrm{p}<0,001)(10$. táblázat), azonban az emelt gerenda gyakorlat során a fent töltött időeredmények is szignifikáns mértékben nőttek ( $W=36 ; p=0,012)$. A gyerekek a második mérés alkalmával átlagosan 11,88 másodperccel tovább tudtak az emelt gerendán egyensúlyozni, mint a fejlesztő torna előtti mérés alkalmával. (11. táblázat)

\section{KO - óvodás kontrollcsoport}

A KO csoport $(\mathrm{n}=19)$ talajgerendán megtett távolság eredményei között szintén szignifikáns mértékủ javulás tapasztalható $(\mathrm{t} 18=-2,689 ; \mathrm{p}=0,015)$, a kontrollcsoport tagjai átlagosan 5,53 \pm 9 méterrel hosszabb távolságokat tudtak megtenni a második mérés alkalmával. (8. táblázat) Ennél a csoportnál azonban a talajgerendán fent töltött időeredmények is szignifikáns mértékben nőttek (W= 82; $\mathrm{p}=0,011)$, az első alkalomhoz képest a gyerekek átlagosan majdnem 15 másodperccel hosszabb ideig tudtak egyensúlyozni. (9. táblázat)

Az emelt gerendán a távolság eredmények között (10. táblázat) szintén szignifikáns növekedést $(\mathrm{t} 18=-2,808 ; \mathrm{p}=0,012)$ látunk. Átlagosan $4 \pm 6,2$ méterrel tudtak többet megtenni, valamint átlagosan 3,84 másodperccel tovább tudtak egyensúlyozni, azonban ez az időeredmények közötti differencia nem tekinthető jelentősnek. (11. táblázat)

\section{VI - iskolás vizsgálati csoport}

A VI csoport $(\mathrm{n}=26)$ eredményei között hasonlóképpen az óvodásoknál tapasztaltakhoz képest, mindkét gerenda gyakorlat esetén szignifikáns növekedést figyelhetünk meg a megtett távolság eredmények között. (8. táblázat, 10. táblázat) Számszerüsítve a javulásokat, a talajgerendán átlagosan 5,54 \pm 9,6 méterrel ( $\mathrm{t} 25=-2,944 ; \mathrm{p}=0,007)$, az emelt gerendán pedig átlagosan 5,08 $\pm 9,6$ méterrel $(\mathrm{t} 25=-3,085 ; \mathrm{p}=0,005)$ hosszabb egyensúlyozás volt tapasztalható.

Az időeredmények a második alkalomra a talajgerenda gyakorlat során átlagosan 5,27 másodperccel növekedtek (9. táblázat), az emelt gerendán viszont átlagosan 0,31 másodperccel csökkentek (11. táblázat) az első méréshez képest. Az eltérések viszont egyik esetben sem szignifikáns mértékűek.

\section{KI - iskolás kontrollcsoport}

Végül a KI csoport $(\mathrm{n}=15)$ eredményeinek összehasonlítására is sor került. Ennél a csoportnál az összes többinél tapasztalthoz képest kizárólag a talaj- 
gerendán megtett távolság eredmények között volt szignifikáns mértékủ a növekedés a második mérés idejére $(\mathrm{t} 14=-3,118 ; \mathrm{p}=0,008)$. Míg a csoport az első méréshez képest a második alkalommal átlagosan 4,87 \pm 6 méterrel tudott tovább egyensúlyozni a talajgerendán (8. táblázat), addig az emelt gerendán átlagosan 1,07 $\pm 5,1$ méterrel rövidebb távolságokat tudtak csak megtenni (10. táblázat), bár ahogy említettük, ez az eltérés nem tekinthető szignifikáns mértékünek az első mérés alkalmával teljesített eredményekhez viszonyítva.

Az időeredmények közötti differenciák csakugyan nem tekinthetők jelentősnek, a talajgerenda gyakorlat során szinte alig átlagosan 0,8 másodperccel voltak rövidebbek (9. táblázat), az emelt gerendán pedig átlagosan 4,13 másodperccel voltak hosszabbak (11. táblázat) az első alkalommal mért eredményekhez viszonyítva.

\section{Talaj-és emeltgerenda-gyakorlatok eredményeinek összehasonlítása}

Végül csoportonként elemeztük a különböző gerenda típusokon elért eredmények közötti hasonlóságokat és eltéréseket. (17-20. ábrák)

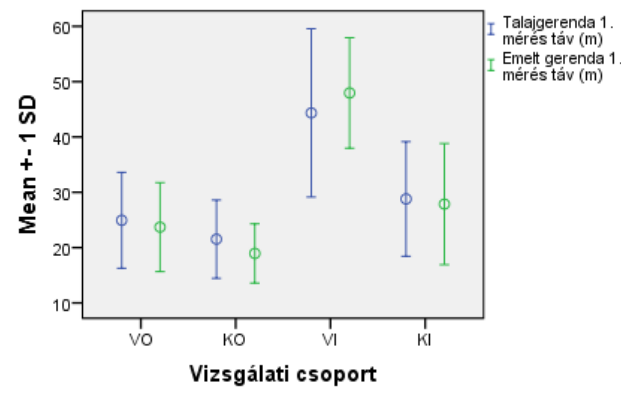

17. ábra

A talaj-és emelt gerenda 1. mérés távolság eredményeinek összehasonlitása (méterben). 


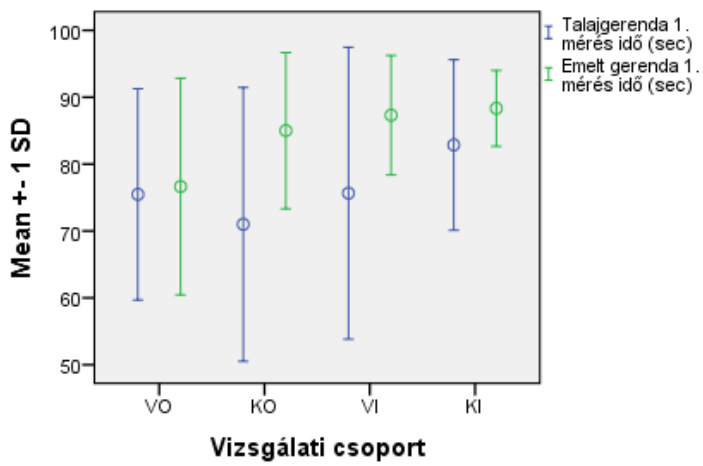

18. ábra

A talaj-és emelt gerenda 1. mérés idóeredményeinek összehasonlitása (másodpercben).

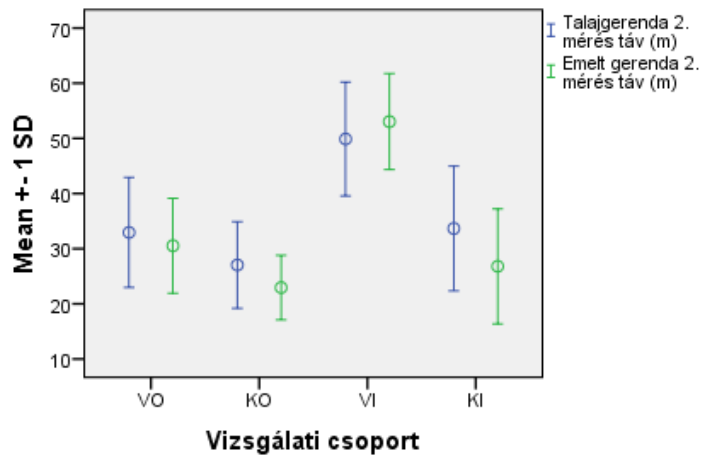

19. ábra

A talaj-és emelt gerenda 2. mérés távolság eredményeinek összehasonlitása (méterben). 


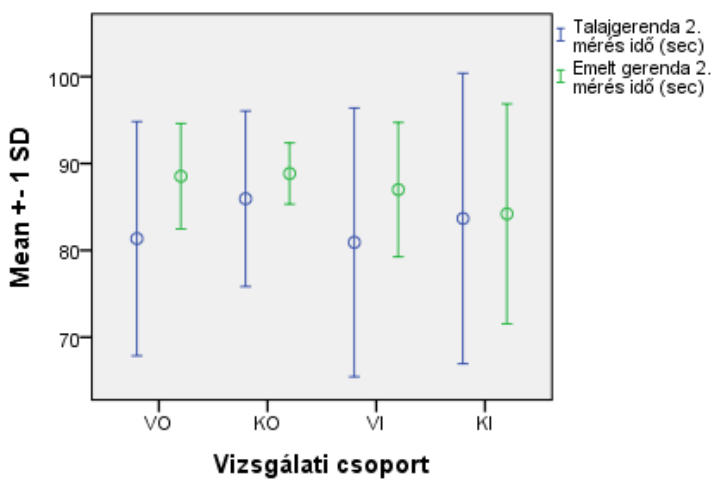

20. ábra

A talaj-és emelt gerenda 2. mérés idö eredményeinek összehasonlitása (másodpercben).

A 12. táblázatban összefoglalva látható, hogy a csoportok távolság mérésenként végzett páros mintás t-próbákhoz tartozó szignifikanciák a nyolc tesztből csupán két esetben mutatnak jelentős eltéréseket a különböző gerendagyakorlatok során elért eredmények között. A számottevő különbségeket pedig mindkét esetben a kontrollcsoportok második méréseinél figyelhetjük meg, méghozzá a talajgerenda gyakorlatok javára. Az eltérés az óvodás kontrollcsoportnál átlagosan 4,11 \pm 4,59 méterrel, az iskolás korcsoportnál pedig átlagosan 6,87 \pm 6,75 méterrel hosszabb távolságok megtételét foglalja magában a talajgerendán az emelt gerendán megtett távolságokhoz képest. Megvizsgálva a többi csoport eredményeit, a VI csoport kivételével a gyerekek minden esetben a talajgerendán tudtak hosszabb távolságokat megtenni, bár az emelt gerendákon elért eredményeikhez viszonyítva a különbségek statisztikailag nem számottevő mértékủek. A VI csoportnál viszont egyedüliként figyelhető meg, hogy az emelt gerendán teljesítettek átlagosan hoszszabb távolságokat.

Az időeredményeket összehasonlító Wilcoxon-próbák szignifikanciái szintén két alkalommal mutatnak jelentős eltéréseket a különböző gerendagyakorlatok során elért eredmények között. (13. táblázat) Ezek az eltérések azonban az első mérések alkalmával voltak megfigyelhetők az óvodás kontrollcsoportnál és az iskolás vizsgálati csoportnál. Előbbi átlagosan 14, utóbbi csoport átlagosan 11,65 másodperccel egyensúlyozott hosszabb ideig az emelt gerendán, a talajgerendán eltöltött időhöz képest. A többi differenciát vizsgálva, bár ezek az eltérések statisztikailag nem számottevő mértékűek, mégis megfigyelhető, hogy minden alkalommal az emelt gerendán való hoszszabb fenntartózkodásról tanúskodnak. 
12. táblázat

A négy csoport talajgerenda versus emelt gerenda távolság eredményei közötti eltérések vizsgálata páros mintás t-próbával

\begin{tabular}{|c|c|c|c|c|c|}
\hline & \multicolumn{2}{|c|}{ Páronkénti eltérések } & \multirow{2}{*}{$\mathbf{t}$} & \multirow{2}{*}{ df } & \multirow{2}{*}{$\mathbf{p}$} \\
\hline & Átlag & Szórás & & & \\
\hline $\begin{array}{l}\text { VO csoport talaj vs. emelt gerenda } \\
\text { 1. mérés (táv, m) }\end{array}$ & 1,24 & 4,78 & 1,066 & 16 & ,302 \\
\hline $\begin{array}{l}\text { VO csoport talaj vs. emelt ge- } \\
\text { renda } 2 . \text { mérés (táv, m) }\end{array}$ & 2,41 & 6,80 & 1,462 & 16 & ,163 \\
\hline $\begin{array}{l}\text { KO csoport talaj vs. emelt ge- } \\
\text { renda 1. mérés (táv, m) }\end{array}$ & 2,58 & 5,63 & 1,997 & 18 & ,061 \\
\hline $\begin{array}{l}\text { KO csoport talaj vs. emelt ge- } \\
\text { renda } 2 \text {. mérés (táv, m) }\end{array}$ & 4,11 & 4,59 & 3,896 & 18 &, $001 *$ \\
\hline $\begin{array}{l}\text { VI csoport talaj vs. emelt ge- } \\
\text { renda 1. mérés (táv, m) }\end{array}$ & $-3,62$ & 12,17 & $-1,514$ & 25 & ,142 \\
\hline $\begin{array}{l}\text { VI csoport talaj vs. emelt ge- } \\
\text { renda 2. mérés (táv, m) }\end{array}$ & $-3,15$ & 11,54 & $-1,393$ & 25 & 176 \\
\hline $\begin{array}{l}\text { KI csoport talaj vs. emelt ge- } \\
\text { renda 1. mérés (táv, m) }\end{array}$ & 0,93 & 8,11 & 0,446 & 14 & 663 \\
\hline $\begin{array}{l}\text { KI csoport talaj vs. emelt ge- } \\
\text { renda } 2 . \text { mérés (táv, m) }\end{array}$ & 6,87 & 6,75 & 3,940 & 14 &, $001 \%$ \\
\hline
\end{tabular}


Három hónapos szenzomotoros torna hatása az óvodások és kisiskolások egyensúlyozó képességére

13. táblázat

A négy csoport talajgerenda versus emelt gerenda idöeredményei közötti eltérések vizsgálata Wilcoxon-próbával

\begin{tabular}{|l|c|c|c|c|}
\hline & $\begin{array}{c}\text { Átlagok } \\
\text { közötti } \\
\text { eltérés }\end{array}$ & $\begin{array}{c}\text { Standar- } \\
\text { dizált } \\
\text { Teszt Sta- } \\
\text { tisztika }\end{array}$ & SE & Sig. \\
\hline $\begin{array}{l}\text { VO csoport talaj vs. emelt gerenda } \\
\text { 1. mérés (idő, sec) }\end{array}$ & $-1,18$ & 0,311 & 11,24 &, 756 \\
\hline $\begin{array}{l}\text { VO csoport talaj vs. emelt ge- } \\
\text { renda 2. mérés (idő, sec) }\end{array}$ & $-7,18$ & 1,892 & 4,76 &, 058 \\
\hline $\begin{array}{l}\text { KO csoport talaj vs. emelt ge- } \\
\text { renda 1. mérés (idő, sec) }\end{array}$ & -14 & 2,244 & 17,60 &, $025^{*}$ \\
\hline $\begin{array}{l}\text { KO csoport talaj vs. emelt ge- } \\
\text { renda 2. mérés (idő, sec) }\end{array}$ & $-2,9$ & 1,214 & 3,71 &, 225 \\
\hline $\begin{array}{l}\text { VI csoport talaj vs. emelt geren- } \\
\text { da 1. mérés (idő, sec) }\end{array}$ & $-11,65$ & 2,945 & 12,73 &, $003^{*}$ \\
\hline $\begin{array}{l}\text { VI csoport talaj vs. emelt geren- } \\
\text { da 2. mérés (idő, sec) }\end{array}$ & $-6,08$ & 1,806 & 12,74 &, 071 \\
\hline $\begin{array}{l}\text { KI csoport talaj vs. emelt geren- } \\
\text { da 1. mérés (idő, sec) }\end{array}$ & $-5,47$ & 1,261 & 4,76 &, 207 \\
\hline $\begin{array}{l}\text { KI csoport talaj vs. emelt geren- } \\
\text { da 2. mérés (idö, sec) }\end{array}$ & $-0,53$ & 0,105 & 4,76 &, 916 \\
\hline
\end{tabular}

Összefoglalva tehát azt mondhatjuk, hogy alapvetően nem jellemző a vizsgálati személyek talaj- és emelt gerenda gyakorlatain elért eredmények közötti szignifikáns mértékủ különbség, azonban a számszerűsített adatokat figyelve a gerendákon megtett távolságok pár kivételtől eltekintve hangsúlyosan a talajgerendákon voltak hosszabbak, míg kivétel nélkül minden csoport az emelt gerendákon töltött fenn hosszabb időt.

\section{Tanulságok}

\section{Dinamikus egyensúlypróbák}

Kutatásunkban a gyermekek dinamikus egyensúlyozó képességének a felmérésére talajgerendán, illetve emelt gerendán dinamikus egyensúlypróbákat végeztünk el. Az első mérés során azt tapasztaltuk, hogy összességében az óvodás korosztály ( $\mathrm{VO}, \mathrm{KO})$ nehezen értette meg a feladatot. Tudvalévő, hogy az óvodások figyelemkoncentrációja, feladattudata nem olyan terjedelmü, mint a kisiskolásoké, akiknél az iskolai környezet folyamatosan fejleszti a fent említett képességeket. Természetesen bemutatással és magyarázattal kezdtük a gyakorlatot, de náluk még ez sem volt elegendő. Általános prob- 
léma volt, hogy mindig a jelzés előtt fordultak vissza. Arra, hogy megértessük velük, hogy a jelzésen túl kell visszafordulni, plüss állatokat helyeztünk a gerenda két végére (kicsivel a jelzéseken túl), és azt mondtuk, hogy az elefántnál és a mackónál kell visszafordulni. Ez végül is müködött! A kisiskolás csoportoknál (VI, KI) ilyen jellegű nehézséget már nem tapasztaltunk. A második mérés alkalmával már az óvodásoknál sem volt ilyen probléma, emlékeztek a feladatra, a plüss állatokat már csak azért használtuk, hogy kicsit játékosabbá varázsoljuk nekik a gyakorlatot.

A vizsgálati óvodás és a vizsgálati iskolás csoport számára a mérés helyszíne ismerős volt, hiszen a Budai Tornász Mühely által tartott torna foglalkozások is a Budapesti Egyetemi Katolikus Gimnázium és Kollégium épületében zajlanak. A vizsgálati óvodás csoportnál az okozott kisebb nehézséget, hogy amíg felmértünk egy-egy gyermeket, addig a többiek nem tudtak egyhelyben ülni. Érthető, hiszen óriási mozgásigénnyel rendelkeznek. Ennek a problémának a kiküszöbölésére alakítottunk ki egy játszósarkot, így aztán egyikőnk lekötötte gyerekeket és egyesével szólítottuk az óvodásokat a méréshez. (5. ábra) A kontrollcsoportnál hasonló jellegű problémánk nem volt, hiszen a környezet, valamint felméréssel egybekötött torna is az újdonság erejével hatott rájuk és csendben figyelték egymást a felmérés alatt. Fáradtságot leginkább az óvodás, illetve az iskolás vizsgálati csoportnál tapasztaltunk, hiszen náluk a felmérés a torna keretein belül zajlott, ami a késő délutáni órákban van. Az egész napos óvodai program, illetve az iskolai órák miatt voltak, akik fáradtabban érkeztek és nehezebben tudtak fókuszálni, de sajnos ezt a problémát nem lehetett kiküszöbölni. Ilyen típusú nehézséggel nem találkoztunk sem az óvodás, sem pedig az iskolás kontrollcsoport esetében. Valószínűleg azért, mert velük előre egyeztetett időpontban, a délelőtti órákban tudtuk elvégezni az egyensúlypróbákat. Az iskolás csoportoknál (VI, KI) egyaránt jellemző volt az egymás közötti versengés és a küzdeni akarás, hogy valamiben a legjobbak legyenek. A gyermekek eredményei motiválóan hatottak egymásra, mert szerettek volna minél jobb eredményt elérni. A talaj- és emelt gerendán történő mérések összehasonlításakor számolnunk kellett azzal, hogy az emeltgerenda-feladat esetében a feladatot nehezített helyzetben kellett végrehajtaniuk a gyerekeknek. A nagyobb magasság olyan plusz nehezítő körülményt jelent, mely alapvetően befolyásolja a teljesítményt. Olyan dimenzió lépett be, amely külön megküzdést igényelt, főleg az óvodás korosztálynál. 


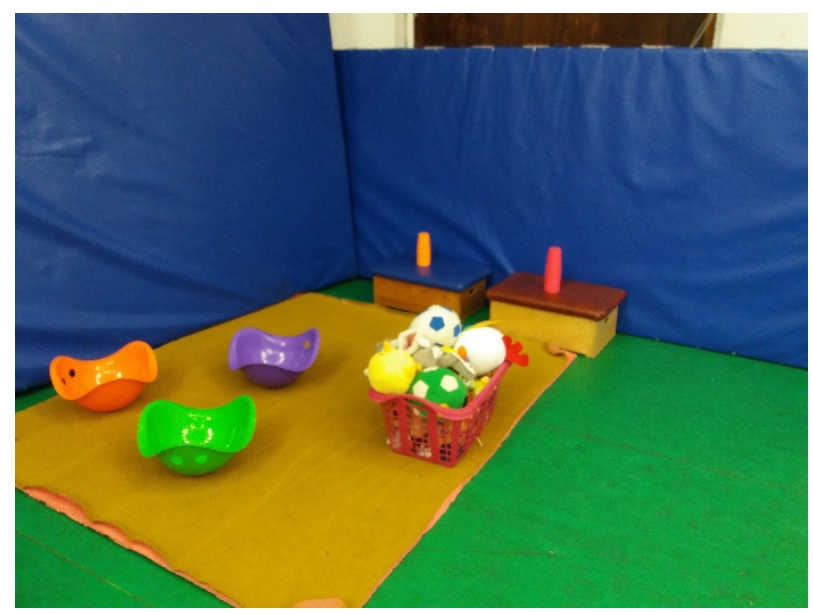

5. ábra

Az óvodások számára kialakitott játszósarok (Forrás: saját fénykép).

A kutatási eredményekből megállapítható, hogy az életkorral nőtt a gyermekek dinamikus egyensúlyozó képessége. Hasonló megállapítást tettek Kakebeeke és munkatársai (2012), hiszen az ő kutatásukból is kiderült, hogy a dinamikus egyensúlyértékek az életkorral javultak. Csirkés és munkatársai (2018) szintén a dinamikus egyensúlyt vizsgálták 5-6 éves óvodások körében. A vizsgálatban szerepeltek biológiai rizikófaktorral, valamint rizikófaktor nélkül született gyermekek. A vizsgálati csoportba tartoztak azok a biológiai rizikófaktorral született gyermekek, akik heti $2 \times 30$ percben egy hat hónapos szenzomotoros fejlesztő tornán vettek részt. Ezek a gyermekek a második mérés alkalmával szignifikánsan jobb eredményt értek el, mint a fejlesztő torna előtti teszten. Saját kutatási eredményeinkkel összehasonlítva megállapítható, hogy mindkét esetben jelentős, pozitív szerepet töltött be a szenzomotoros foglalkozásokon való részvétel a test dinamikus egyensúlyozó képességének a fejlesztésében.

\section{Következtetések}

Az első feltételezésünk, miszerint a kisiskolás gyermekek összességében magasabb eredményeket érnek el, mint az óvodáskorú gyermekek csak részben igazolódott be, ugyanis az ANOVA vizsgálatok és a Welch-próbák eredményei valóban, már az első és a második mérések alkalmával is jeleztek szignifikáns eltéréseket a négy nagy csoport eredményei között. Azonban a post hoc tesztek eredményei alapján látható, hogy szignifikánsan magasabb ered- 
ményeket egyedül az iskolás vizsgálati csoport (VI) ért el a többi csoporthoz képest. Az iskolás kontrollcsoportra is igaz ugyan, hogy az első mérések alkalmával magasabb eredményeket ért el az óvodás csoportokhoz képest, azonban ezek csak számszerüsített eltérések, statisztikailag nem bizonyulnak szignifikáns mértékűnek. A fejlesztő torna utáni mérések alkalmával pedig már csak a talajgerenda gyakorlatok esetén érvényesek, ugyanis az emelt gerendán a vizsgálati óvodás csoport számszerüsítve magasabb értékeket produkált az iskolás kontrollcsoporthoz képest.

Második hipotézisünk a vizsgálati óvodás, illetve a vizsgálati iskolás csoportokról szólt, és feltételeztük, hogy a három hónapos intervenció hatására mindkét csoport jobb eredményeket ér majd el. Ez a hipotézis mindkét gerendatípuson (talaj-, illetve emelt gerenda) a megtett távolság értékek tekintetében teljes mértékben beigazolódott. A vizsgálati csoportok mindkét korosztályban valóban szignifikánsan hosszabb távolságokat tudtak megtenni a fejlesztő torna utáni mérés alkalmával. Az időeredmények tekintetében azonban a hipotézis egyedül az óvodás csoport emelt gerenda gyakorlatánál igazolódott be, a többi esetben az időeredmények közötti eltérések statisztikailag nem tekinthetők szignifikáns mértékűnek.

A harmadik hipotézisünkkel azt feltételeztük, hogy összességében a vizsgált személyek emelt gerendán alacsonyabb eredményeket érnek el, mint talajgerendán. Az eredményekből kiderül, hogy nehéz konkrét választ adni erre a hipotézisre, mivel a távolság és időeredmények teljesen ellentétesek egymással. Összefoglalva tehát azt mondhatjuk, hogy alapvetően nem jellemző a vizsgálati személyek talaj- és emelt gerenda gyakorlatain elért eredmények közötti szignifikáns mértékű különbség, azonban a számszerüsített adatokat figyelve a gerendákon megtett távolságok pár kivételtől eltekintve hangsúlyosan a talajgerendákon voltak hosszabbak, míg kivétel nélkül minden csoport az emelt gerendákon töltött fenn hosszabb időt.

Az eredmények függvényében valószínűsíthető, hogy a rugalmas és instabil eszközökkel végzett szenzomotoros torna már három hónap elteltével javította a vizsgálatban szereplő óvodások és kisiskolások dinamikus egyensúlyozó képességét. További három hónap elteltével szignifikánsabb eredményt, nagyobb eltérést várunk az egyensúlyi értékek tekintetében. Azonban meg kell állapítanunk, hogy az eddigi változások sem kizárólagosan csak az egyensúlyi edzés hatására történhettek. Valószínűsíthető, hogy a szenzitív időszak normál érésének erőteljesebb a hatása, az egyes mozgásformák (például járás) továbbfejlődésére, valamint a gyermekek életvitelének mozgásos összetevői az egyensúlyozó képességre nézve ugyancsak pozitív változást eredményeznek. Mindezen tényezőket is figyelembe véve, egyértelműen javasoljuk a szenzomotoros tornát, mint az óvodai nevelés egyik alternatív módját.

Győri (1988) jól gondolja, hogy a 3-6 éves gyermekek fejlődését determináló komplex (pszichológiai, biológiai, motorikus és szociális) hatások nemcsak nagy hatásfokkal müködnek, hanem pótolhatatlanok és megismé- 
telhetetlenek is. Az ebben az életkorban elmulasztott lehetőségek, illetve a fizikai képességfejlesztés szenzitív időszakai a későbbiekben már ugyanolyan hatásfokkal soha sem térnek vissza. Ezért van döntő jelentősége annak, hogy alaposan megismerjük a gyermekeket, valamint az őket érintő fejlődési törvényszerüségeket.

Hewes (2014) megállapítja, hogy a spontán szabad játék, amely lehetővé teszi a kisgyermekek számára a játék azon dimenzióinak felfedezését, amelyek kaotikusnak, értelmetlennek és zavarónak tűnhetnek a felnőttek számára, kulcsfontosságúak egészségük és jólétük szempontjából. A szabad játékban a gyermekek aktívan feltárják saját társadalmi és fizikai erejüket a világgal és más gyermekekkel szemben. Mivel minden gyermek más gyermekkel vesz részt a játék társadalmi kontextusában, megértik, hogy mit jelent az irányítás, és mit jelent az irányítás nélküli állapot. A kisgyermekek rutinszerüen kihívásnak tekintik a játék szabályait, például a csúszdán való lecsúszás helyett felmásznak a csúszdára. Amikor a gyerekek játszanak, nagyon erősnek érzik magukat. A játszótéri gumiasztalról történő elugrás egyet jelent a gravitációval való találkozással és a repülés erejének megtapasztalásával. Ez a fajta játék, melynek hatására kialakul a vesztibuláris ingerlés, fokozottabb térbeli tudatosságot eredményez. A gyermek egyensúlyozó képessége észrevétlenül, különösebb beavatkozás és irányítás nélkül fejlődik. Izgalmas az, hogy az egyensúlyt az egyensúlyhiány szándékos feltárása és megtapasztalása révén erősítik meg.

Az iskoláskor előtt, 5-7 éves korra a nagymozgások kivitelezésében már szükséges a gyermek megfelelő fejlettsége, mert ez lehet az alapja a finommozgások kialakulásának. Farmosi (1999) úgy véli, hogy a finomabb szemkéz koordináció, amelyre a tárgykezelés is épül, csak a már meglévő durvább szem-test koordináció alapján jöhet létre. A felsorolt mozgásformák előfeltételét képezik a finomabb mozgásminták kiépülésének. A funkcionális mozgásformák megfelelő elsajátításán keresztül vezet az út az iskolaérettséget minősítő mozgásfejlettségig (Pintér, 1997; Lakatos, 2000; Marton-Dévényi et al., 2002; Lakatos, 2005, Tótszölősyné, 2006; Cools et al., 2009; Birontiené, 2010; Király \& Szakály, 2011).

\section{Összefoglaló}

A gyermekek egészséges testi, lelki fejlődéséhez szükséges a rendszeres és sokoldalú mozgás. Speciális fejlesztéssel rendkívüli eredményeket érhetünk el már óvodás- és kisiskolás korban is, hiszen ezekben az életszakaszokban a gyermekek rendkívül fogékonyak és szenzitívek az őket ért hatásokra és változásokra. Azért is rendkívül fontos az egyensúlyozó képesség fejlesztése már óvodáskorban, mert a későbbiekben, az egyensúlyrendszer fejlődésének zavara akár tanulási nehézégeket és viselkedési problémákat is okozhat. Vizsgálatunk célja volt, hogy bebizonyítsuk, hogy egy három hónapos szenzomotoros torna hatására a vizsgálati csoportba tartozó gyermekek egyensúlyértékei javulnak, valamint az, hogy a speciális fejlesztő tornákon résztvevő gyermekek jobb eredményt érnek el 
a kontrollcsoportban szereplő társaikhoz képest. Kutatásunkban 36 óvodás- és 41 iskoláskorú gyermek vett részt. A gyermekeket két vizsgálati csoportra (VO, VI) és két kontrollcsoportra (KO, KI) osztottuk. VO csoport (5-6 éves óvodások) és VI csoport (7-10 éves kisiskolások) három hónapon keresztül heti 2x60 perces szenzomotoros tornán vettek részt, a kontrollcsoportba tartozó óvodások (KO), illetve kisiskolások (KI) pedig az óvodai testnevelés és az iskolai mindennapos testnevelés programját követték. Mind a négy csoport dinamikus egyensúlyát talaj- és emelt gerendán mértük a három hónapos fejlesztés előtt és után. A vizsgálati csoportok eredményei közötti eltéréseket külön az 1. mérésen és külön a 2. mérésen belül varianciaanalízissel vizsgáltuk. Ezt követően elemeztük a két mérés közötti eltéréseket páros t-próbákkal. Ahol a feltételek nem teljesültek, a méréseken belül a csoportok összehasonlítására Mann-Whitney U-próbát, a két mérés közötti teljesítménybeli különbségeket pedig Wilcoxon-próbával teszteltük. Az eredményekből megállapítottuk, hogy az intervenció hatására a vizsgálati csoportban szereplő 5-6 éves óvodás és 7-10 éves iskolás gyermekek jobban teljesítettek a második mérés alkalmával a gerendán megtett távolság értékek tekintetében az első méréshez képest. Az időeredményeket vizsgálva egyik korosztálynál egyik mérésén belül sem volt szignifikáns mértékű eltérés a vizsgálati és a kontrollcsoport teljesítményei között.

\section{Irodalom}

Bar-Haim, Y., \& Bart, O. (2006). Motor function and social participation in kindergarten children. Social Development, 15(2), 296-310. https://doi.org/10.1111/j.1467-9507.2006.00342.x

Birontiené, Z. (2010). Changes in the physical fitness of 5 to 7-year-old-children in the promotion of their physical maturing for school. Tiltai, 4, 133-143.

Cools, W, De Martelaer, K, Semaey, C, \& Andries, C. (2009). Movement skill assessment of typically developing preschool children: A review of seven movement skill assessment tools. Journal of Sports Science and Medicine, 8(2), 154-168.

Csirkés, Zs, Bretz, K, F. Földi, R, \& Hamar, P. (2018) Effects of instability training devices on dynamic balance in preschoolers born with biological risk factors. Early Child Development and Care, 182(13), 2113-2125.https://doi.org/10.108 0/03004430.2018.1439939

Dubecz J. (2009). Általános edzéselmélet és módszertan. Jegyzet a középfokú edzőképzés részére. Rectus Kft.

DeOreo, K, \& Keogh, J. (1980). Performance of fundamental motor tasks. In Corbin, C. B. (Ed.), A textbook of motor development. WCB, 76-91.

Drowatzky, J. N., \& Zuccato, E. C. (1967). Interrelationships between selected measures of static and dynamic balance. Research Quarterly. American Association for Health, Physical Education and Recreation, 38(3), 509-510. https://doi.org/10.1080/10671188.1967.10613424 
Három hónapos szenzomotoros torna hatása az óvodások és kisiskolások egyensúlyozó képességére

D’Hondt, E., Deforche, B., Vaeyens, R., Vandorpe, B., Vandendriessche, J., Pion, J., Philippaerts, R., de Bourdeaudhuij, I., \& Lenoir, M. (2011). Gross motor coordination in relation to weight status and age in 5- to 12-year-old boys and girls: A cross-sectional study. International Journal of Pediatric Obesity, 6, 556-564. https://doi.org/10.3109/17477166.2010.500388

Farmosi, I. (1999). Mozgásfejlődés. Dialóg Campus Kiadó.

Fetz, F., \& Kornexl, E. (1973). Praktische Anleitung zu sportmotorischen Tests. Limpert-Verlag GmbH.

Fruttus, L., \& Kaló, J. (1981). Stabilometer. Budapest.

F. Földi, R., \& Boda-Ujlaky, J. (2014). Vestibular regulation in children with ADHD: a neuropsychological perspective. Psychologia Hungarica, 2(2), 66-74.

Gallahue, D, \& Donnely. F. (2003). Developmental physical education for all children. Human Kinetics.

Giacalone, W. R., \& Rarick, G. L. (1985). Dynamic balance of preschool children as reflected by performance on beam-walking tasks. The Journal of Genetic Psychology, 146(3), 307-318. https://doi.org/10.1080/00221325.1985.9914460

Gribble, P. A., \& Hertel, J. (2003). Considerations for Normalizing Measures of the Star Excursion Balance Test. Measurement in Physical Education and Exercise Science, 7(2), 89-100.

https://doi.org/10.1207/S15327841MPEE0702_3

Gyebnár, V. (1982). Stabilometer Typ.: EM-05.05. STRUKTÚRA Sz.V.

Győri, P. (1988). Edzetlen 3-6 éves gyermekek biológiai fejlettsége és motoros aktivitása. In Makkár M. (Ed.), I. Országos Sporttudományos Kongresszus. I-II. kötet. 347-364.

Harsányi, L. (2000). Edzéstudomány I. Dialóg Campus Kiadó.

Hirtz, P., Hotz. A., \& Ludwig, G. (2004). Mozgáskompetenciák-egyensúlyozás. Dialóg Campus Kiadó.

Kakebeeke, T. H., Locatelli, I., Rousson. V., Caflisch, J., \& Jenni, O. G. (2012). Improvement in gross motor performance between 3 and 5 years of age. Perceptual and Motor Skills, 114(3), 795-806.

https://doi.org/10.2466/10.13.25.PMS.114.3.795-806

Kasuga, K., Demura, S., Aoki, H., Shin, S., Sugiura, H., \& Uchida, Y. (2012). Sex and age-level differences of walking time in preschool children on an obstacle frame. Journal of Physiological Anthropology, 31(1).

https://doi.org/10.1186/1880-6805-31-8

Kinzey, S. J., \& Armstrong, C. W. (1998). The reliability of the star-excursion test in assessing dynamic balance. Journal of Orthopaedic E Sports Physical Therapy, 27(5), 356-360.

https://doi.org/10.2519/jospt.1998.27.5.356 
Király, T., \& Szakály, Zs. (2011). Mozgásfejlödés és a motorikus képességek fejlesztése gyermekkorban. Dialóg Campus Kiadó.

Koltai, J., \& Nádori, L. (1983). Sportképességek fejlesztése. Sport.

Lakatos, K. (2000). Az állapot-és mozgásvizsgáló teszt. Xfer Mühely.

Lakatos, K. (2005). A mozgásérettség vizsgálatának jelentösége a tanulási zavarok korai felismerésében. Doktori értekezés. Semmelweis Egyetem Testnevelési és Sporttudományi Kar.

Marton-Dévényi, É., Szerdahelyi. M., Tóth, G., \& Keresztesi, K. (2002). Alapozó Terápia Tanulmány (1994-1999). Alapozó terápiák Alapítvány.

Mészáros, J. (1990). A szervrendszerek szerkezetének és működésének fejlődési jellegzetességei. In Mészáros, J. (Ed.), A gyermeksport biológiai alapjai. Sport.

Meszler, B, Tékus, É., \& Váczi, M. (2015). Motorikus képességek mérése. Pécsi Tudományegyetem Természettudományi Kar Sporttudományi és Testnevelési Intézet.

Nagykáldi, Cs. (1971). A sportolók pszichológiai felkészítésének módszerei. In Nádori, L. (Ed.) A sport és testnevelés idöszerü kérdései. Sport.

Nádori, L. (1991). Az edzés elmélete és módszertana. Magyar Testnevelési Egyetem.

Niederer, I., Kriemler, S., Gut, J., Hartmann, T., Schindler, C., Barral, J., \& Puder, J. J. (2011). Relationship of aerobic fitness and motor skills with memory and attention in preschoolers (Ballabeina): A cross-sectional and longitudinal study. BMC Pediatrics, 11.

https://doi.org/10.1186/1471-2431-11-34

Pappné Gazdag, Zs. (2009). Egyensúlyozás-Koordinációs kompetenciák fejlesztése. Flaccus Kiadó.

Pintér, É. (1997). Természetes gyermeki megnyilvánulások. In Porkolábné Balogh, K., Balázsné Szűcs, J., \& Szaitzné Gregorits, A. (Eds.), Komplex prevenciós óvodai program. Trefort Kiadó.

Reiman MP. Functional testing in performance. Human Kinetics, Champaign, ILinois, 2009: 1009.

https://doi.org/10.5040/9781492596882

Rácz, K., \& Bretz, K. (2008). Nagycsoportos óvodások stabilométeres eredményei. VI. Országos Sporttudományi Kongresszus Kiadványfüzete.

Sarabon, N., Rosker, J., Loefler, S., \& Kern, H. (2010). Sensitivity of body sways parameters during quiet standing to manipulation of support surface size. Journal of Sports Science E Medicine, 9(3), 431-438.

Shimada, H., Obuchi, S., Kamide, N., Shiba, Y., Okamoto, M., \& Kakurai, S. (2003). Relationship with dynamic balance function during standing and walking. American Journal of Physical Medicine E Rehabilitation, 82(7), 511-516.

https://doi.org/10.1097/01.PHM.0000064726.59036.CB 
Három hónapos szenzomotoros torna hatása az óvodások és kisiskolások egyensúlyozó képességére

Shumway-Cook, A., \& Woollacott, M. H. (1985). The growth of stability: postural control from a development perspective. Journal of Motor Behavior, 17(2), 131-147. https://doi.org/10.1080/00222895.1985.10735341

Tinetti, M. E. (1986). Performance-oriented assessment of mobility problems in elderly patients. Journal of the American Geriatrics Society, 34, 119-126. https://doi.org/10.1111/j.1532-5415.1986.tb05480.x

Tótszölősyné Varga, T. (2006). Mozgásfejlesztés az óvodában. Tótszölősyné Varga Tünde magánkiadás.

Tsigilis, N., Zachopoulou, E., \& Mavridis, T. (2001). Evaluation of the specificity of selected dynamic balance tests. Perceptual and Motor Skills, 92(3), 827-833. https://doi.org/10.2466/pms.2001.92.3.827

Ulrich, B., \& Ulrich, D. (1985). The role of balancing ability in performance in fundamental motor skills in 3-, 4-, and 5-year-old children. In Clark, S. E., \& Humphrey, J. H. (Eds.) Current Selected Research in motor development. Princeton Book Company, 87-97.

Wang, W. Y., \& Chang, J. J. (1997). Effects of jumping skill training on walking balance for children with mental retardation and Down's syndrome. Kaohsiung Journal of Medical Sciences, 13(8), 487-495. https://doi.org/10.1177/0269215510382929

Westcott, S., Lowes, L., \& Richardson, P. (1997). Evaluation of postural stability in children: current theories and assessment tools. Physical Therapy, 77(6), 629-645 https://doi.org/10.1093/ptj/77.6.629

Wrisley, D. M., \& Kumar, N. A. (2010). Functional gait assessment: concurrent, discriminative, and predictive validity in community-dwelling older adults. Physical Therapy, 90(5), 761-773. https://doi.org/10.2522/ptj.20090069

\section{Internetes források}

http://www.topendsports.com/testing/tests/balance-beam.htm http://www.topendsports.com/testing/tests/balance-bass.htm 


\section{Csirkés, Zs. \& Csongor, N. E. \\ The effect of a three-month sensorimo- tor training on the balancing ability of preschool and school-aged children}

The aim of our study was to investigate the effects of a 3-month sensorimotor balance intervention on dynamic balance in 5-6-year old preschoolers and 7-10-year old primary school children. 36 preschoolers and 41 school aged children participated in this study, and were assigned to two experimental groups (VO, VI) and two control groups (KO, KI). VO group (5-6-year old preschoolers) and VI group (7-10-year school aged children) attended a 60-min sensorimotor training two times a week for 3 months. KO and KI groups followed the regular Physical Education schedule. High and low floor beam-walking tasks were used to measure dynamic balance. Differences between the results of the groups were examined separately in pre and post-test by analysis of variance. Subsequently, the differences between the two measurements were analyzed by paired $t$-tests. Where conditions were not met, Mann-Whitney U test was used to compare the groups within the measurements, and Wilcoxon's test for differences in performance between pre and post-tests. It was found that 5-6-year-old preschool children and 7-10-year-old primary school children of the experimental group achieved better distance results on balance beam in post test. Examining the time results, there was no significant difference between the performances of the experimental and the control groups.

Keywords: balance, preschoolers, school-aged children, sensorimotor training, unstable surface 